\title{
Patent Assertions: Are We Any Closer to Aligning Reward to Contribution?
}

Fiona Scott Morton, Yale School of Management and NBER

Carl Shapiro, University of California, Berkeley

\section{Executive Summary}

The 2011 America Invents Act (AIA) was the most significant reform to the United States patent system in over 50 years. However, the AIA did not address a number of major problems associated with patent litigation in the United States. In this paper, we provide an economic analysis of post-AIA developments relating to patent assertion entities (PAEs) and standard-essential patents (SEPs). For PAEs and SEPs, we examine the alignment, or lack of alignment, between the rewards provided to patent holders and their social contributions. Our report is mixed. Regarding PAEs, we see significantly closer alignment between rewards and contributions, largely due to a series of rulings by the Supreme Court. Legislation currently under consideration in Congress would further limit certain litigation tactics used by PAEs that generate rewards unrelated to contribution. We also see some notable developments relating to SEPs, especially with the recent reform to the patent policies of the Institute of Electrical and Electronics Engineers (IEEE), a leading standard-setting organization (SSO) and with several recent court decisions clarifying what constitutes a fair, reasonable and nondiscriminatory (FRAND) royalty rate. However, other steps that could better align rewards with contributions on the SEP front have largely stalled out, particularly because other major SSOs do not seem poised to follow the lead of the IEEE. Antitrust enforcement in this area could further align rewards and contributions. 


\section{Introduction}

In September 2011, President Obama signed the AIA, the most significant reform to the patent system since the 1950s. The AIA made major changes in how the U.S. Patent and Trademark Office (PTO) reviews patent applications, grants patents, and considers postgrant challenges to issued patents. These changes were intended to improve patent quality and shorten patent pendency, two goals with widespread support.

The passage of the AIA did not put an end to calls for patent reformfar from it. In the wake of the AIA, evidence has mounted that the rules governing patent litigation are in need of adjustment: questionable litigation tactics employed by PAEs attracted widespread attention; the smartphone patent wars heated up, fueled by a combination of high stakes and legal uncertainty; and controversy swirled around the appropriate antitrust or contractual limits on how patent holders could assert patents that are essential to practicing widely adopted technology standards.

While casual observers may be perplexed that the AIA did not "fix" the US patent system, upon closer inspection, this should not come as a surprise. The AIA did not address many of the litigation tactics being used by PAEs or the remedies available to owners of patents that have been found in court to be valid and infringed. Nor did the AIA address the problems associated with SEPs or the treatment of patents by the International Trade Commission (ITC). ${ }^{1}$ These are the aspects of the patent system we address here.

The flaws in the patent litigation system studied here result from a divergence between the reward that a patent holder can obtain by asserting its patent and the social contribution generated by the research and development activities that led to the issuance of that patent. For this reason, when evaluating various reforms to the patent system, we do not ask whether these reforms increase or decrease the rewards to patentees. Rather, we ask whether these reforms better align the private rewards to patentees with their social contributions. This approach to patent reform is developed in greater detail in Shapiro (2007).

Following this approach, we devote attention here to certain patent litigation tactics that a patent holder can employ to generate returns that are out of proportion to the social contribution resulting from the $\mathrm{R} \& \mathrm{D}$ activities that led to the issuance of the patent in question. While the organizational form of the entity using these tactics is not directly relevant to this question, the most questionable tactics are often used 
by entities that specialize in patent assertion. Typically, these entities either acquire patents to monetize them or inherit patents from unsuccessful operating companies. Scott Morton and Shapiro (2014) offer some explanations for this observed relationship between strategy and structure. Most notably, entities with little or no revenues from their own products and services are not vulnerable to countersuits accusing them of patent litigation. For them, patent litigation is a form of "asymmetric warfare." Furthermore, entities that specialize in asserting and monetizing patents are likely to suffer little harm from alienating target firms because, unlike many operating companies, they do not need to cooperate with these target firms on other fronts and, indeed, may benefit from developing a reputation for employing scorched-earth patent litigation strategies.

Ultimately, the ability of a patent holder to use the patent system to extract revenues from target firms must be based on the costs it can impose on them. These costs generally come in three forms. First, a target firm must bear litigation expenses to defend itself against allegations of patent infringement. We discuss how certain litigation tactics employed by patent holders can impose large and asymmetric litigation costs on patent defendants, even if the underlying patent infringement claim is weak. Second, a target firm that loses the patent litigation will be forced to pay infringement damages. Typically, these damages come in the form of reasonable royalties. We address how the courts assess reasonable royalties in patent cases. Third, a target firm that loses the patent litigation may be subject to an injunction preventing it from selling infringing products. We discuss how and when the courts issue such injunctions, especially for SEPs, and how the ITC issues exclusion orders, which can have a similar effect. All of this points to patent reforms that affect litigation costs, the determination of reasonable royalties, and the use of injunctions, regardless of the organizational form taken by the party asserting the patent. ${ }^{2}$

In this paper, we provide an update on how well the US patent litigation system delivers rewards to patent holders commensurate with their research and development (R\&D) contributions in the wake of the AIA. Overall, we believe that the rewards to patent holders have moved closer to their social contributions on several fronts, especially due to a series of major decisions by the Supreme Court, but movement on some other fronts appears to be blocked. We frame the analysis in the paper using two constructs: the underlying quality of the patent and the type of cost a patent holder can create for the implementer, 
as described in the preceding. We apply this framework to two main areas: PAE activity and the assertion of SEPs. For each of these areas, we identify where progress has been made and where significant problems remain.

Before looking more closely at specific changes in the US patent litigation system, it is worth pausing to emphasize the crucial distinction between reforms to the patent system that affect the issuance of new patents versus the assertion of existing patents. Reforms that affect the issuance of new patents, such as those in the AIA, necessarily have only a gradual impact on patent litigation as the newly issued patents over time grow to comprise a larger share of the total stock of outstanding patents and litigated patents. To illustrate, in Fiscal Year 2011, during which the AIA was passed, the PTO issued 221,350 utility patents, but there were roughly 10 times as many utility patents in force, some 2.2 million. ${ }^{3}$ Among litigated patents, Love (2013) shows that the average lag from patent application to the end of all litigation with that patent is 16.1 years for patents asserted by nonpracticing entities. ${ }^{4}$ In 2013, the median patent asserted by a nonpracticing entity in patent litigation had a priority date 15 years earlier, all the way back in $1998 .{ }^{5}$ Clearly, reforms that apply to the flow of new patent applications, no matter how effective, can only very gradually address problems with the assertion and monetization of the much larger existing stock of patents. This observation alone explains why the passage of the AIA did not put an end to calls for reform of the patent litigation system.

In section III, we look at the tactics used by PAEs, commonly known as "patent trolls." PAEs are organizations whose primary or sole activity is the assertion of patents against target firms. The goal and expertise of PAEs is to efficiently monetize patents by collecting royalties through the licensing of their patents and by winning patent damage awards in court. In their purest form, PAEs do not produce or sell products or service. Over the past several years, PAEs have attracted considerable attention among business executives and those interested in public policies toward intellectual property rights and innovation.

In section IV, we explore problems associated with SEPs, regardless of the form taken by entity owning and asserting them. SEPs present a unique set of challenges at the intersection of antitrust and patent law and policy. The problems of patent holdup and royalty stacking can be especially severe for SEPs. Some SSOs are modifying their rules to deal with these problems. The federal courts are assisting with this process. As a result of these changes, the ITC has become a policy outlier, based 
on its authority to issue exclusion orders preventing the importation of infringing products into the United States.

\section{Three Cost Categories Underlying Patent Monetization}

\section{A. Litigation Costs}

Patent holders can impose litigation costs on target firms. Of course, this is a natural and inevitable consequence of any innovation reward system predicated on intellectual property rights. However, concerns about misalignment between reward and contribution arise if owners of low-quality patents can impose substantial costs on target firms. We define a patent as "low quality" with respect to a given patent assertion if the probability that the patent will be found valid and infringed in that assertion is low. ${ }^{6}$

In the extreme case of sham litigation, the patent holder knows full well that the target firm is not infringing its patent but, nonetheless, sues for patent infringement in order to extract a settlement. This fact pattern fits within the definitions of a "nuisance suit" or "frivolous litigation," as those terms are defined in the law and economics literature. However, the same principle applies more generally if the costs that a patent holder can impose on target firms are disproportionate to the quality of the patent being asserted. Misalignment concerns are especially great if (a) litigation costs are highly asymmetric as between the patent holder and the target firm, or if (b) the entity asserting the patents finds it profitable to persist with infringement claims that are unprofitable on their own terms (due to low patent quality) in order to develop a reputation as a tough and persistent asserter of patents. As we discuss in the following, both of these conditions are often satisfied in patent infringement actions brought by PAEs.

\section{B. Reasonable Royalties}

\section{Background}

Virtually all patent holders who sue for patent infringement seek damages from the party they are accusing of patent infringement. Patent damages can come in the form of lost profits or reasonable royalties. For PAEs and SEPs, our primary topics here, damages almost always come in the form of reasonable royalties. 
The basic idea behind reasonable royalties is straightforward: they are meant to measure the royalties that would be negotiated ex ante between the patent holder and the infringing party, assuming that the patents involved are valid and infringed. In this context, "ex ante" is interpreted to mean the date just before the infringement began although an economically more precise statement would be the date just before the infringing party made significant investments specific to the use of the patented technology.

The classic case identifying the factors that determine reasonable royalties in the United States is the Georgia Pacific case. ${ }^{7}$ The Court of Appeals for the Federal Circuit (CAFC) has sanctioned the use of the so-called Georgia-Pacific factors to frame the inquiry into the determination of reasonable royalties. ${ }^{8}$ Many commentators have pointed out that the Georgia-Pacific factors often do not provide the most useful framework for the determination of reasonable royalties. ${ }^{9}$ For our purposes here, two primary issues stand out, neither of which is well captured by the original Georgia-Pacific factors: royalty stacking and patent hold-up.

First, the presence of other patents that read on the same product can and should affect the reasonable royalties for any one such patent. In the presence of royalty stacking, it is important to determine the aggregate level of royalties that will likely be applied to the product in question. This is especially important for products that comply with standards for which there are many SEPs, as discussed by Lemley and Shapiro (2007). The use of an appropriate base on which to compute royalties can help mitigate problems associated with royalty stacking. Recent decision by the CAFC to calculate royalties based on the revenues from the "smallest saleable patent-practicing unit" are quite helpful in this respect. ${ }^{10}$

Second, when implementers make substantial investments that are specific to practicing the patent in question, the prospect for opportunism by patent holders, that is, patent holdup, can be substantial. Given the probabilistic nature of patents and difficulties interpreting patent claims, it can be very difficult for implementers making investments in product development to avoid exposing themselves to patent infringement actions.

\section{Empirical Evidence}

Lex Machina (2015) reports data on the patent damage awards resulting from the 42,805 patent cases filed and terminated in federal court from 
2000 through 2014. Among these cases, 13.4\% reached a merits decision, but only $1.8 \%$ involved a compensatory damages award for the plaintiff. ${ }^{11}$ Of the total $\$ 14.7$ billion total awarded in compensatory damages, $\$ 8.8$ billion was for reasonable royalties, $\$ 3.2$ billion was for lost profits, and $\$ 2.7$ billion did not specify as between reasonable royalties and lost profits. ${ }^{12}$ Lex Machina data show clearly that total reasonable royalty damages grew sharply, from an average of about $\$ 190$ million per year during 2004-2007 to an average of nearly $\$ 1.2$ billion per year during 2008-2013. ${ }^{13}$ Care must be taken in interpreting these aggregate figures because they are heavily influenced by a relatively small number of very large awards.

Lex Machina (2014a) reports that the average patent damage award increased by $28 \%$ from $\$ 27.2$ million in 2012 to $\$ 34.7$ million in 2013 . This $\$ 34.7$ million average was driven by few very large awards, notably a $\$ 1$ billion award from DuPont to Monsanto regarding genetically modified seeds and two awards from Samsung to Apple, one for \$599 million and one for $\$ 290$ million. The median patent award was much smaller than the average award. The median patent damage award grew by $22 \%$, from $\$ 1.03$ million in 2012 to $\$ 1.26$ million in $2013 .{ }^{14}$

Both Lex Machina (2014b) and PwC (2014) report a decline in total patent damages from 2012 to 2013. Lex Machina (2015) reports total damages awarded during 2014 of $\$ 2.2$ billion. One should not make too much of the data on total patent damages from any one year, given the magnitude of the mega-awards. However, $\mathrm{PwC}$ reports that the median damages awarded has been declining. By their measure, the median award during 2000-2004 was $\$ 7.5$ million, falling to $\$ 4.9$ million during 2005-2009 and \$4.3 million during 2010-2013..$^{15}$

PwC finds a significant difference between the median damages awarded to practicing versus nonpracticing entities: $\$ 2.5$ million versus $\$ 8.5$ million during 2010-2013. ${ }^{16}$ They report that the median award to nonpracticing entities grew, from $\$ 7.3$ million during 2005-2009, while the median award to practicing entities declined, from $\$ 4.3$ million during 2005-2009. These data do not allow us to determine how the mix of patents asserted by practicing versus nonpracticing entities or the tactics used by these two type of entities, shifted over time. PwC also sees a dramatic difference between median damages awarded by judges versus juries. During 2010-2013, the median award from a judge was $\$ 0.4$ million, while the median award from a jury was $\$ 15.0$ million ${ }^{17}$

Reasonable royalties were awarded more than twice as often as lost profits during the 2010-2013 time period. ${ }^{18}$ 


\section{Injunctions}

The second major remedy available to patent holders is a permanent injunction preventing the infringing firm from continuing to make, use, or sell infringing products. Until about 10 years ago, a patent holder that won its patent infringement suit was automatically granted a permanent injunction, with very few exceptions. This practice fit with the rubric that a patent gives its owner the right to exclude others from practicing the patented technology.

In 2006, however, the Supreme Court issued a major ruling that substantially narrowed the circumstances under which patent holders can obtain permanent injunctions. ${ }^{19}$ The Supreme Court's ruled in the eBay case that a patent holder seeking a permanent injunction must satisfy the same four-factor test that the courts apply in other areas of the law. In particular, a patent holder "must demonstrate (1) that it has suffered an irreparable injury; (2) that remedies available at law, such as monetary damages, are inadequate to compensate for that injury; (3) that, considering the balance of hardships between the plaintiff and the defendant, a remedy in equity is warranted; and (4) that the public interest would not be disserved by an injunction."

For our purposes here, looking at PAEs and SEPs, the key point is that permanent injunctions are strongly disfavored under $e$ Bay for patent holders who widely license their patents and are seeking reasonable royalty damages. We note with respect to PAEs that the unavailability of an injunction under $e B a y$ is not driven by the business form of the patent holder but rather by the distinction between reasonable royalty damages and lost profit damages. ${ }^{20}$ In the following, we discuss the conditions under which owners of SEPs can obtain injunctions to prevent other firms from using the technology covered by the SEPs. Such injunctions can be very powerful weapons because they prevent the implementer from practicing the standard, which can have dramatic commercial consequences for standards that are widely accepted and practiced.

\section{Retreat of the Trolls?}

\section{A. What Harms Are Caused by PAEs?}

Over the past several years, many observers have expressed concerns that PAEs are exploiting the patent litigation system in a manner that 
discourages innovation, effectively imposing a "tax" on firms that develop and sell innovative goods and services. ${ }^{21}$

We studied PAEs and expressed such concerns in Scott Morton and Shapiro (2014). In that paper, we reported data from RPX showing that the number of patent cases filed grew from 2,472 in 2010 to 5,411 in 2013 and that the proportion of these cases filed by nonpracticing entities grew from $30 \%$ to $67 \% .{ }^{22} \mathrm{RPX}$ data indicate that PAEs accounted for $91 \%$ of the patent infringement actions brought by nonpracticing entities in 2013 and $89 \%$ in $2014 .{ }^{23}$ We also developed a theoretical model to assess the impact of PAEs on innovation and used that model to identify the key empirical parameters that determine whether entities that purchase patents to assert and monetize them generally promote or harm innovation. The available empirical evidence presented in that paper indicates that, for plausible values of the parameters identified in our model, such entities generally harm rather than promote innovation. Numerous legal scholars have provided empirical evidence regarding the costs PAEs impose on target firms that develop new products and services, reaching similar conclusions. ${ }^{24}$ We consider it telling that PAEs rarely transfer technology to implementers, either directly or indirectly. Feldman and Lemley (2015) find that all of the respondents in their survey who took patent licenses from nonpracticing entities reported receiving technical knowledge along with a patent license in only $0 \%$ to $10 \%$ of their nonpracticing entity licenses. ${ }^{25}$ Feldman and Lemley summarize their results this way:

With almost complete unanimity, respondents who took licenses from NPEs, rarely received technical knowledge, transfer of personnel (including consulting agreements) or joint ventures along with the patents license. Thus, when companies licensed patents from NPEs, the indirect markers that might suggest even the potential for future innovation were almost entirely absent. ${ }^{26}$

\section{B. Federal Trade Commission (FTC) Study}

The FTC described its plans for a "Patent Assertion Entity Study," along with a solicitation of comments from the public, in the Federal Register on May 19, 2014. There followed a comment period. The Office of Management and Budget approved the proposed study on August 8, 2014. ${ }^{27}$ This FTC study will focus on companies conducting business in the wireless communications sector. The FTC is now seeking an exhaustive catalog of information and documentation from PAEs, wireless chip manufacturers, and other technology firms involved in this sector, 
covering patent activity beginning January $1,2009 .{ }^{28}$ Here are two examples of the type of questions the FTC is asking:

- How do PAEs acquire patents; who are the prior patent owners; and how do they compensate prior patent owners?

- How do PAEs engage in assertion activity, that is, how do they behave with respect to demands, litigation, and licensing?

The FTC has hoped to produce its report by December 2015 as no party has moved to quash, and respondents seem to be complying with the request. ${ }^{29}$ However, the study requests a great deal of data, so, working carefully, it may take the lawyers and the economists at the FTC a significant period of time to complete their analysis. We expect this report will provide important empirical evidence about markets for patents and the extent and cost of PAE activity. This study strikes us as a fine example of how the FTC can use its statutory authority to conduct industry studies. ${ }^{30}$

\section{MPHJ Technology Investments Case}

The FTC alleged that MPHJ Technology Investments made deceptive threats accusing more than 16,000 small business of patent infringement. In November 2014, MPHJ and its law firm agreed to settle with the FTC on charges of "deceptive sales claims and phony legal threats" against thousands of small businesses. ${ }^{31} \mathrm{MPHJ}$ had acquired patents relating to network scanning technology, which the firm then proceeded to assert against many small businesses. MPHJ sent letters to these businesses informing them that they were infringing on MPHJ's patents and that they should purchase a license for thousands of dollars if they planned on using the technology in the future. The FTC settlement provides that any future deception would result in a fine of $\$ 16,000$ per demand letter. ${ }^{32}$ This high-profile case seems closer to fraud than many other PAE assertions. Therefore, while it establishes a valuable precedent and deterrent to the most egregious and widespread demand-letter campaigns, it seems unlikely to have much impact on PAE activity involving larger individual damages claims directed at specific, selected targets.

\section{Declining Returns to the PAE Business Model}

There is considerable evidence that PAEs have experienced recent setbacks. The latest data from RPX show a meaningful decline in the num- 
ber of patent infringement cases brought by nonpracticing entities, from 3,673 in 2013 to 2,791 in $2914 .{ }^{33}$ In 2014, nonpracticing entities accounted for $63 \%$ of all such cases, down slightly from $67 \%$ in $2013 .{ }^{34}$ Target companies with less than $\$ 100$ million in revenue accounted for $62 \%$ of the unique defendants newly facing allegations of patent infringement. ${ }^{35}$

Whether one applauds or bemoans the activities of PAEs, one of the best indicators of whether the tide has turned regarding patent assertion may be trends in the market value of the types of patent portfolios that PAEs have been purchasing. We are not aware of any index that accurately measures changes in the overall value of a fixed set of patents, correcting for patent quality, coverage, duration, and so forth. We do, however, find it illuminating that Erich Spangenberg, the owner of IPNav, one of the leading PAEs, has become quite bearish on the value of patents. At the end of 2014, he predicted a massive decline in the number of patent lawsuits filed along with major write-downs in the value of patent portfolios. ${ }^{36}$ Along similar lines, Lu (2015) examines the prices at which patent portfolios are sold, concluding that the AIA "significantly depressed the transaction prices of patent assets." ${ }^{37}$

The Rockstar consortium is viewed by some industry observers as a PAE. This is the group of large technology firms that bid for the Nortel patent portfolio when Nortel went bankrupt. Members include Apple, Microsoft, Blackberry, Sony, and others, but notably not Google, which put in the original stalking horse bid for the portfolio. The portfolio originally included 6,000 patents and sold for a record-setting $\$ 4$ billion. Members distributed 2,000 patents amongst themselves (each member preserving a royalty-free license to the entire portfolio) and the remaining 4,000 patents were sold in December 2014. RPX, the patent defense firm, purchased the patents for one-quarter of the original auction price, or $\$ 900$ million, although the portfolio does not include perhaps the most valuable 2,000 patents. ${ }^{38}$ RPX does not actively assert patents.

Another firm that has been aggressive in asserting its patents, Qualcomm, has also suffered some economic setbacks recently. China, being the location of manufacture of a large share of the world's handsets, is the source of about one half of Qualcomm revenue. ${ }^{39}$ One of the three agencies in China responsible for enforcing the Chinese Anti-Monopoly Law (AML), the National Development and Reform Commission (NDRC), accused Qualcomm of violating the AML. Qualcomm paid a fine of almost one billion dollars. Some analysts believe that Qualcomm violated the AML by not making licenses for its communication SEPs available on FRAND terms. Other analysts believe that the NDRC inter- 
vened to help local firms obtain lower royalty rates in their negotiations with Qualcomm. As part of the settlement, Qualcomm agreed to make a number of changes to its licensing practices and to lower its royalty rate by $35 \% .^{40}$ The nonprice changes include no tying of SEPS to non-SEPs, no required reciprocal licenses, and not basing the royalty on the final price of the handset. ${ }^{41}$

In 2013, Intellectual Ventures (IV), a very large PAE, began a series of 13 lawsuits against large financial institutions. These cases continued into 2014. ${ }^{42}$ Capital One prevailed in April 2014 when Judge Anthony Trenga dismissed IV's lawsuit. Judge Trenga took the additional step of invalidating all remaining patents in IV's litigation, claiming that "IV's patents were simply abstract ideas." ${ }^{\prime 3}$ This nullification of IV's patents foreshadowed the conclusion of Alice v. CLS Bank, which strictly limited patents on business methods and software. ${ }^{44}$ It seems likely that the value of many PAE holdings will be reduced by the Alice ruling, particularly to the extent that those holdings contained software and business method patents.

In February 2014, IV cut five percent of its workforce, most of whom were "attorneys and engineers who worked for IV's large patent acquisition funds." ${ }^{45}$ In August 2014, IV reduced its workforce by an additional $20 \%$ (roughly 140 people of its 700 employee workforce). ${ }^{46} \mathrm{Co}-$ founder and chief technology officer (CTO) Edward Jung characterized these layoffs as a natural part of IV's evolution as, after getting IV's patent funds up and running, the company needed fewer people to "sort through patents, acquire them covertly, think up complementary ideas, and deal with the associated paperwork." ${ }^{\prime 7}$ An alternative explanation is that the returns to being a PAE have fallen, causing the firm to reduce the scale of its activities.

Meanwhile, IV has been publicly promoting two new strategies that follow the procompetitive narrative for PAEs. ${ }^{48}$ The first is invention by IV itself: "Critics who only saw IV as a giant IP collector misjudged the company, he [Jung] says. It will soon be pumping out dozens of revolutionary products." ${ }^{49}$ The IV Invention Lab has spun out several firms, including TerraPower (nuclear power), Kymeta (satellites), and Evolv Technologies (image detection). ${ }^{50}$

Second, IV has a new program, Intellectual Venture's Invention Network (IVIN), which may help individual inventors monetize patents while also helping IV acquire more patents. The network promises to bring individual inventors and their patents into "a network of thousands of inventors who get paid for their ideas." Here is some key language from the IVIN website: ${ }^{51}$ 
- "Whether you're working alone in your garage or collaborating at one of our participating institutions, IV's inventor network offers you access to an extensive information database which includes detailed analyses of important markets, products, and technologies. You can also enjoy inventor community benefits such the sharing of ideas and mentoring."

- "Beyond upfront payment and patenting of selected ideas, inventors share profits and downstream royalties generated from licensing and commercialization."

- "For selected inventions, we help fund the costs of securing worldwide protection. This may include patenting fees, marketing, research and proof-of-concept work, and commercialization-which can exceed US\$50,000 per invention."

- "Our international reach enables us to maximize the value of your invention by bundling it with other inventions from around the world."

Intellectual Ventures invites inventors to join and submit their patents, writing: "Have a patent to sell? When your invention is purchased by IV, we'll give it global reach. Submit your patent to us and we'll respond with a fair valuation. ${ }^{\prime 52}$ It remains to be seen whether there are productive inventors who wish to participate in the network. ${ }^{53}$

The setbacks faced by PAEs may have caused the recent decline in PAE litigation, but the level of PAE litigation remains very high by historical standards, and the prospect of juries awarding very large damages, possibly disproportionate to the patent holder's social contribution, remains. In February 2015, a jury in Tyler, Texas, ruled against Apple and awarded Smartflash, a classic PAE, \$533 million for willful infringement by Apple iTunes of three of its seven patents related to data storage and payment management. ${ }^{54}$ Apple continues to insist that it invented the disputed technology and has indicated that it plans to appeal. We do not know the details of the specific patent claims or damages calculations in that case, but there is little doubt that Apple makes for an attractive target given its enormous revenues. Smartflash has already filed a second lawsuit against Apple as well as cases against Google, HTC, and Samsung.

\section{Legislative Attempts to Reduce the Cost of Litigation}

Patent reform is one of all-too-few areas in economic policy where truly bipartisan legislation seems possible in today's polarized political en- 
vironment. The AIA was very much a bipartisan effort, passing the Senate $95-5$ and the House $304-117.55$

Now, there is bipartisan interest in Congress in passing legislation designed to control what are seen as abuses of the patent litigation system, especially by PAEs. In December 2013, H.R. 3309, the Innovation Act, introduced by Representative Goodlatte, passed the House 325-91. ${ }^{56}$ Several senators introduced similar legislation during 2013, but the Senate did not move on patent reform in $2014 .{ }^{57}$ Many observers expected that legislation similar to H.R. 3309 would become law in 2015. Representative Goodlatte reintroduced H.R. 3309 as H.R. 9 in February 2015. The provisions contained in the new H.R. 9 provide an excellent guide to the types of reforms most likely to be enacted. Here are some of the key provisions:

Fee Shifting. H.R. 9 calls for the losing party in a patent case to pay the reasonable fees and other expenses incurred by the prevailing party "unless the court finds that the position and conduct of the nonprevailing party or parties were reasonably justified in law and fact or that special circumstances (such as severe economic hardship to a named inventor) make an award unjust." This is a change from current law, which only calls for the prevailing party to be awarded fees in "exceptional cases." 58

Shielding Final Customers. Some PAEs have adopted the strategy of suing (or threatening to sue) final customers who purchase and use a product for patent infringement rather than the manufacturer of the allegedly infringing device. The MPHJ Technology Investments case described in the preceding is one (striking) example. This tactic, which has much in common with nuisance suits, is designed to induce many final customers to pay royalties rather than face the costs of defending a patent infringement case. H.R. 9 would require courts to allow manufacturers to intervene as codefendants in any patent infringement suit brought against their customers and to put on hold the infringement suit against a customer so long as the customer agrees to be bound by the judgment entered against the manufacturer.

Heightened Pleading Requirements. Currently, some patent holders bringing infringement cases provide very little information on just what products are allegedly infringing the patents in suit or on the basis for the infringement allegation. H.R. 9 would require the patent holder's initial pleading to provide more detail on the claims that are infringed; the specific product, feature, method or process that is alleged to infringe those claims; and more.

Ownership Transparency. The bill would require plaintiffs to disclose 
to the PTO, the parties, and the court much more about the parties who are bringing the litigation and who have a financial interest in the litigation. Plaintiffs would have to disclose the owner of the patent, the party with the right to enforce the patent, any party with a financial interest in the patent or the plaintiff, and the parent company of those parties.

Limitations on Discovery. Likewise, under current law, each party in a patent dispute bears the cost of providing evidence in its possession to the opposing party. H.R. 9 would maintain this approach for "core documentary evidence" but require the requesting party to pay the cost of producing all evidence outside this category. This addresses the asymmetry that arises when a PAE patent infringement case against a target company causes substantial discovery costs on the target company but much smaller costs for the PAE.

As of January 2016, there appears to be a decent chance that a bill similar to H.R. 9 will be passed by Congress and signed by President Obama in 2016. ${ }^{59}$ Legislation along these lines would meaningfully reduce patent assertions that are currently profitable primarily because of the litigation costs they can impose on target firms who do not settle. Put differently, legislation along these lines would go a long way to eliminating "patent nuisance suits." Because the returns to such suits have little if any relation to patent quality, reducing the returns associated with this type of patent assertion would lead to better overall alignment of rewards and contributions. Increased transparency of the parties with a financial interest in patent assertions, along with financial incentives relating to fee shifting, might well help create a betterfunctioning market for intellectual property rights.

\section{E. White House Proposals to Reduce the Cost of Patent Litigation}

Less than two years after President Obama signed the AIA, the White House called for "bold legislative action" to "protect innovators from frivolous litigation and ensure the highest quality patents in our system." ${ }^{60}$ The White House simultaneously released a report entitled "Patent Assertion and U.S. Innovation," which emphasized that PAE activity harms innovation and economic growth. ${ }^{61}$ This report concluded the following:

Thus, the best approach to resolving today's patent troll problem is not to ban firms specialized in patent assertion, but rather to reduce the extent to which legal rules allow patent owners to capture a disproportionate share of returns to investment. We see three main areas for improvement: clearer patents with a 
high standard of novelty and non-obviousness, reduced disparity of litigation costs between patent owners and technology users, and greater adaptability of the innovation system to challenges posed by new technologies and new business models.

The White House made seven legislative recommendations. ${ }^{62}$ Two of these recommendations are quite similar to provisions found in H.R. 9. One recommendation is to "permit more discretion in awarding fees to prevailing parties in patent cases" to serve "as a sanction for abusive court filings." A second recommendation is to "protect off-the-shelf use by consumers and businesses by providing them with better legal protection against liability for a product being used off-the-shelf and solely for its intended use." ${ }^{63}$

The White House also announced five executive actions, four of which involve the PTO. ${ }^{64}$

\section{F. US Patent and Trademark Office Actions to Raise Patent Quality}

Following the lead of the White House, the PTO has undertaken a number of "Executive Actions on High Tech Patent Issues." ${ }^{65}$ We comment here on the PTO executive actions relating to patent quality and transparency.

In 2013, the PTO attempted to require patent owners to disclose themselves to the public through registering patent ownership changes with the PTO. The reasoning was that this would make it more difficult for PAEs to "ambush" implementers, make it easier for implementers to seek out patent holders from whom they want a license, and help clarify what blocking technologies already exist for a firm looking to enter a technological area. This effort failed due to objections from patent owners who prefer their holdings to remain secret.

The PTO is revising its patent assignment database to make it easier to search. But submission of ownership information to that database remains voluntary. We are skeptical that this voluntary approach will generate the transparency benefits identified by the PTO, especially for PAEs, some of which go to great lengths to conceal information about the patents they own. ${ }^{66}$ Our understanding is that mandatory submission of ownership information would require legislation.

The PTO's executive action on "Clarity in Patent Claims" could significantly improve patent quality. The goal of this action is to more clearly define the boundaries of patents. If successful, this action would help implementers to avoid inadvertent patent infringement and re- 
duce patent litigation. Improving clarity in patent claims and tightening functional claiming is a major ongoing project at the PTO. Currently, it is far too early to tell what its impact will be.

The PTO's executive action "Crowdsourcing Prior Art" also is promising but as yet unproven. Currently, the PTO is evaluating the process by which patent examiners receive information about prior art from third parties.

In February 2015, the PTO issued a "Request for Comments on Enhancing Patent Quality." ${ }^{\prime 67}$ In March 2015, the PTO held a two-day "Patent Quality Summit" to discuss its proposals to improve patent quality. This is a promising initiative in its early stages. As noted in the preceding, improving the quality of newly issued patents can only gradually reduce the costs associated with low-quality patents, given the large stock of patents that have already been issued.

\section{G. Supreme Court Decisions Lower Returns from Improper Assertion}

The 2013-2014 term at the Supreme Court included one decision that promises to have a dramatic impact on PAEs and several others that shift the balance in patent litigation modestly away from patent holders. Perhaps just as important, in a series of unanimous decisions, the Supreme Court signaled that the specialized appeals courts that handles patents, the CAFC, had veered badly off course. The Supreme Court made it crystal clear that the CAFC had departed from Supreme Court precedent and improperly constructed a set of rules regarding patent litigation that were overly rigid and overly favorable to patent holders. ${ }^{68}$ In this sense, the Supreme Court complemented the White House and Congress in pushing back against excessively broad and vague patents as well as patent litigation abuses. ${ }^{69}$

\section{Alice: Abstract Ideas Put on a Computer are not Patentable}

The biggest patent case of the 2013-2014 term at the Supreme Court was unquestionably Alice vs. CLS Bank, 134 S. Ct. 2347 (2014). This case involved a patent covering intermediated settlement in financial markets that uses a computer system to track the balances of different trading parties, only executing if both parties to the trade have sufficient funds. The unanimous decision states: "We hold that the claims at issue are drawn to the abstract idea of intermediated settlement, and that merely requiring generic computer implementation fails to transform 
that abstract idea into a patent-eligible invention." The Supreme Court emphasized that it was merely following precedent going back 150 years, under which "laws of nature, natural phenomena, and abstract ideas are not patentable."70 The Supreme Court explained that "laws of nature, natural phenomena, and abstract ideas are the basic tools of scientific and technological work," and that "monopolization of those tools through the grant of a patent might tend to impede innovation more than it would tend to promote it" and, thus, be contrary to the goal of the patent laws as specified in the Constitution.

The Supreme Court stated explicitly that "the method claims, which merely require generic computer implementation, fail to transform that abstract idea [intermediated settlement] into a patent-eligible invention." ${ }^{\prime 71}$ This is the critical teaching from Alice: patent claims that combine an abstract idea with a computer implementation that is not itself inventive are not patentable. Many observers believe that Alice sounds the death knell for all or virtually all business methods patents and a great many software patents. If this proves to be the case, the Supreme Court will have dramatically reduced the existing stock of patents that can effectively be asserted in the information technology sector. So far, indications are that Alice is indeed having a dramatic effect on business method patents and software patents. A PAE now faces a much greater likelihood that its patent will be invalidated in court. Even more important in the short term, defendants in patent infringement cases are having considerable success in having their cases dismissed on the grounds that the patent claims asserted against them cover subject matter that is not patentable after Alice. ${ }^{72}$ The PTO (2014) has already issued new guidelines to examiners implementing the more stringent standards from Alice and withdrew hundreds of patent applications from allowance following the new guidelines. ${ }^{73}$

Octane Fitness: Fee Shifting to PAEs is made Easier

The Supreme Court also dramatically reversed the CAFC regarding the circumstances under which the losing party in a patent litigation can be required to pay the legal fees of the prevailing party. The CAFC had made fee shifting in patent cases virtually impossible, requiring that the prevailing party establish that the losing party acted with "subjective bad faith" and that the losing party's case was "objectively baseless." In a pair of decisions, a unanimous Supreme Court brushed aside the CAFC's standard, making it far easier for the prevailing party to estab- 
lish the "exceptional circumstances" under which fee shifting is permitted by the Patent Act. $^{74}$ The Court said it would be sufficient to show that the losing party made unusually weak arguments or engaged in litigation strategy abuses. The Court also lowered the burden of proof required for the trial judge to make such a finding. Plus, lest there be any doubt that the Supreme Court was telling the CAFC to back off, the Supreme Court ruled that the CAFC could only reverse the trial judge's award of fees to the prevailing party if the trial judge abused his or her discretion, greatly limiting the role of the CAFC in comparison with the de novo review standard that the CAFC had previously applied.

With these two decisions, the Supreme Court has probably gone about as far as it can to reign in abusive patent litigation tactics through fee shifting, given that the statute confines fee shifting to "exceptional circumstances." Note that H.R. 9 would go considerably further by creating a presumption that the losing party in a patent case pays the fees of the prevailing party.

\section{Medtronic: Declaratory Judgment Actions}

Patent holders generally decide whether, when, and against whom to assert their patents by initiating a patent infringement action. This can be problematic for an implementer that believes it is not infringing a given patent but does not want to make specific investments that would suffer capital losses if its products or services are later found to infringe. Declaratory judgment actions thus help align patentee reward and contribution by limiting patent holdup.

Patent law provides a mechanism for an implementer to press the issue and obtain a judicial determination as to whether or not it is indeed infringing a valid patent: by filing a declaratory judgment action. In MedImmune vs. Genentech 549 U.S. 118 (2007), the Supreme Court reversed the CAFC and ruled that an implementer who has signed a patent license could file a declaratory judgment action. In this manner, the implementer can pay royalties and avoid liability for patent infringement while having the matter resolved in court.

However, the CAFC had placed an obstacle in front of an implementer filing a declaratory judgment action: the burden of proving infringement would shift from the patent holder (who bears this burden when bringing a patent infringement action) to the implementer. In Medtronic v. Mirowski, 134 S. Ct. 843 (2014), the Supreme Court reversed the CAFC and held that this burden remains with the patent holder. 
The Medtronic case is a useful step to facilitate the earlier determination of whether a patent is valid and infringed. As explored by Lemley and Shapiro (2007), Farrell and Shapiro (2008), and Shapiro (2010), there are efficiency benefits of making such determinations before implementers make specific investments.

Nautilus: Patent Quality and Clarity of Claims

Many observers have expressed concerns that the claims in many software patents are vague, making it hard for implementers to determine whether they are likely to be found infringing. Menell (2014) nicely articulates this problem and proposes solutions.

Yet again, the Supreme Court found that the CAFC had leaned too far in favor of patent holders. In Nautilus Inc. v. Biosig Instruments, Inc. 134 S. Ct. 2120 (2014), the Supreme Court significantly altered the standard under which patent claims would be found overly vague and, thus, invalid.

The CAFC had established a very lenient standard: a claim was considered clear enough so long as it was not "insolubly ambiguous." In other words, if there existed any way to clarify the claim and make it definite, the claim would withstand challenge. The Supreme Court dismissed this extreme approach, ruling that a patent claim is indefinite "if the claim fails to inform, with reasonable certainty, those skilled in the art about the scope of the invention." This decision is likely to have a major impact on how patent claims are drafted, improving patent quality and reducing the amount of patent litigation.

\section{Standard Essential Patents}

\section{A. Background}

We now discuss problems that have arisen regarding patents that are essential to compliance with product standards, so-called SEPs. SSOs have established procedures by which they choose a technological path for a standard. Because that path might involve patented innovations, the SSO also will typically have an Intellectual Property Rights (IPR) policy. If the standard cannot be implemented without practicing (using) a particular patent, that patent is said to be an SEP. The IPR policy of an SSO articulates what member firms must disclose concerning their patents that may be essential and also what licensing obligations members must commit to should they have any SEPs. The usual licensing 
commitment of an SSO requires what are known as FRAND terms. As stated previously, FRAND refers to Fair, Reasonable, and Nondiscriminatory.

SSOs create or enhance market power by the joint action of their members in limiting competition among technologies and, instead, agreeing on a single standard, typically one in which several or many members hold IPRs. This joint action can be acceptable for society because it trades off technology competition against the potentially speedy adoption of one efficient standard-provided the SSO limits the ex post license terms for SEPs so as to constrain the exercise of the substantial market power necessarily enjoyed by the owner of an SEP in a successful standard. However, SSOs typically specify very little as to the meaning of the words "fair" or "reasonable" in the FRAND commitment. This is, perhaps, partially because of uncertainty about future demand and costs but also because some of their members gain from ambiguity in the meaning of FRAND.

The root cause of many problems in the SEP market described in the following is this vague nature of the FRAND commitments. If the FRAND commitment contained more detail on what actions and rights were permitted or forbidden, the upper range of demands would shrink, thereby making it more difficult for a patent holder to engage in holdup. ${ }^{75}$ However, SSOs operate by consensus and typically have at least some members who profit from the status quo. Those members can use due process within the organization to slow or block reform. Tactics include filibustering discussions and votes, requiring subcommittees to engage in extensive study, and organizing or purchasing allies to vote against reform. Dysfunction of FRAND enforcement has been noted by policymakers for many years. In January 2013, the US Department of Justice (DOJ) and the US PTO issued a joint policy statement regarding SEPs. ${ }^{76}$ The National Research Council recently released a detailed study of the IPRs of a number of SSOs, including a series of recommendations for SSO and government policies. ${ }^{77}$

Somewhat surprisingly, SEPs fare significantly less well when litigated in federal court than do other patents. When asserting SEPs in federal Court, patent holders prevailed approximately $29 \%$ of the time, far lower than the $68 \%$ win rate for non-SEPs. ${ }^{78}$

\section{B. IEEE Sharpens the Definition of FRAND}

There had been little progress at major SSOs in clarifying just what a FRAND commitment entails until February 2015, when the IEEE be- 
came the first major SSO to successfully reform its IPR policy. The proposed changes to the IEEE IPR policy were approved at three different levels of committees and then finally by the IEEE board of governors. ${ }^{79}$ The IEEE reforms have several important components. ${ }^{80}$ Together, these reforms substantially impact two of the three categories of patent assertion costs, namely patent damages and injunctions.

The FRAND Commitment Travels with the Patent

The new IEEE IPR policy requires that the FRAND commitment remains binding when the patent is sold. In the absence of this requirement, a successful business strategy would be to agree to FRAND and then later sell the patents to a licensor who could then claim that he was not so bound. This reform protects the integrity of the FRAND commitment, thereby limiting patent damage awards and injunctions based on SEPs by increasing the number of FRAND-encumbered patents and, thus, protecting more implementers who relied upon the FRAND commitment.

Like many other observers, we have been perplexed as to why it took so long for the IEEE to clarify that the FRAND commitment "travels with the patent" and why other major SSOs have not already adopted a similar provision into their IPR policies.

No Bundling of Non-SEPs with SEPs

The new IEEE IPR policy prohibits the owner of SEPs from bundling them with other IPRs as a condition of licensing those SEPs. Parties may choose broad cross-licensing voluntarily, but it may not be a requirement. The SEP owner is required to offer a simple license covering all of the SEPs that read on a given standard. This change protects a licensee from bundling or tying that might raise a royalty rate above the FRAND level or otherwise enable evasion of the FRAND commitment.

Clarification of What Constitutes a "Reasonable" Royalty Rate

Importantly, IEEE takes a stand on defining what constitutes a "reasonable" royalty rate. In particular, the first paragraph in the following states that the value associated with a patent claim excludes the value resulting from the inclusion of that claim's technology in the standard. 
This principle has been advanced by the US competition agencies for many years because it helps prevent holdup and associated inefficiencies.$^{81}$ The text of the new IEEE policy is reproduced in the following:

"Reasonable Rate" shall mean appropriate compensation to the patent holder for the practice of an Essential Patent Claim excluding the value, if any, resulting from the inclusion of that Essential Patent Claim's technology in the IEEE Standard. In addition, determination of such Reasonable Rates should include, but need not be limited to, the consideration of:

- The value that the functionality of the claimed invention or inventive feature within the Essential Patent Claim contributes to the value of the relevant functionality of the smallest saleable Compliant Implementation that practices the Essential Patent Claim.

- The value that the Essential Patent Claim contributes to the smallest saleable Compliant Implementation that practices that claim, in light of the value contributed by all Essential Patent Claims for the same IEEE Standard practiced in that Compliant Implementation.

- Existing licenses covering use of the Essential Patent Claim, where such licenses were not obtained under the explicit or implicit threat of a Prohibitive Order, and where the circumstances and resulting licenses are otherwise sufficiently comparable to the circumstances of the contemplated license. ${ }^{82}$

The three "optional" bullets will presumably have influence on how courts interpret the term "reasonable" in FRAND licensing under the IEEE policy. The first bullet helps cabin the FRAND demand of a licensor by focusing attention on the value of the patented technology, for example, the chipset used in communications and not the additional features of the handset or game console or automobile. The second bullet focuses attention on the problem of "royalty stacking." Given that many standards have hundreds or even thousands of claimed SEPs, a reasonable royalty must take this into account so that total payments of implementers remain reasonable. The third bullet essentially says that licensors should not point to royalty rates negotiated under the threat of an injunction and use them as a "competitive" benchmark.

\section{Limits on Seeking or Enforcing Injunctions}

The new IEEE IPR policy makes a huge change in a second type of assertion cost by limiting the use of injunction and exclusion orders:

The Submitter of an Accepted LOA who has committed to make available a license for one or more Essential Patent Claims agrees that it shall neither seek nor seek to enforce a Prohibitive Order based on such Essential Patent Claim(s) 
in a jurisdiction unless the implementer fails to participate in, or to comply with, the outcome of, an adjudication, including an affirming first-level appellate review, if sought by any party within applicable deadlines, in that jurisdiction by one or more courts that have the authority to: determine Reasonable Rates and other reasonable terms and conditions; adjudicate patent validity, enforceability, essentiality, and infringement; award monetary damages; and resolve any defenses and counterclaims. In jurisdictions where the failure to request a Prohibitive Order in a pleading waives the right to seek a Prohibitive Order at a later time, a Submitter may conditionally plead the right to seek a Prohibitive Order to preserve its right to do so later, if and when this policy's conditions for seeking, or seeking to enforce, a Prohibitive Order are met. ${ }^{83}$

This policy means that as long as the implementer is complying with adjudication procedures that will eventually produce appropriate monetary damages for the SEP holder, the SEP holder may not pursue an injunction. Importantly, an implementer who thinks the patents are not valid, not essential, or not infringed may pursue litigation on those grounds and be safe from the threat of injunction until a determination has been made by a court or arbitrator. Note that an SEP holder can still seek an injunction against an implementer that will not participate in a formal system to resolve the licensing dispute or who has a judgment against it that it refuses to pay.

\section{Department of Justice Business Review Letter}

In February 2015, the Antitrust Division issued a business review letter (BRL) regarding the changes in the IEEE IPR policies. ${ }^{84}$ This BRL is an important document because it clarifies how the DOJ evaluates certain business practices associated with SEPs. This BRL also explains the DOJ's current thinking regarding SEPs and the FRAND commitment, going well beyond the specifics of the IEEE policy. ${ }^{85}$ The DOJ BRL states the following:

The inherent ambiguity in the meaning of the terms "reasonable" and "nondiscriminatory," however, can limit the benefits of RAND licensing commitment. Greater clarity and transparency may facilitate further the adoption and implementation of standards, thereby increasing the benefits that consumers derive. ${ }^{86}$

Here we see a clear opinion from the DOJ that ambiguity regarding the meaning of the FRAND commitment harms consumer welfare. This is not without import as there are PAEs whose position is that ambiguity preserves incentives to participate in the SSO process. In a sec- 
tion entitled "Prohibitive Orders," the DOJ BRL goes on to state the following:

The threat of exclusion from a market is a powerful weapon that can enable a patent owner to hold up implementers of a standard. Limiting this threat reduces the possibility that a patent holder will take advantage of the inclusion of its patent in a standard to engage in patent holdup. ${ }^{87}$

In a section entitled "Reciprocity-Grantbacks," the DOJ BRL also takes a general position against the compulsory tying of SEPs to other patents.

These prohibitions [on tying] will reduce the possibility that a holder of a RAND encumbered patent could leverage that patent to force a cross-license of, among other things, a potential licensee's differentiating patents and limit the potential for anticompetitive tying. A compulsory cross-license can, in some cases, decrease incentives to innovate. ${ }^{88}$

The letter goes on to make clear that voluntary cross licensing can be procompetitive. The DOJ's BRL of the new IEEE policy concludes with this statement:

The Department concludes that the Update has the potential to benefit competition and consumers by facilitating licensing negotiations, mitigating hold up and royalty stacking, and promoting competition among technologies for inclusion in standards. The Department cannot conclude that the Update is likely to harm competition. Further, to the extent that there are any potential competitive harms, the Department concludes that the Update's potential procompetitive benefits likely outweigh those harms. Accordingly, the Department has no present intention to take antitrust enforcement action against the conduct you have described. ${ }^{89}$

In our experience, this is about as enthusiastic as the US DOJ gets in its business review letters.

\section{Combined Impact at IEEE and Beyond}

Together, the IEEE IPR policy changes are very substantial. They ensure the permanence of the FRAND commitment, prohibit tying using SEPs, and they sharply limit injunctions based on SEPs. Furthermore, they provide substantial guidance on what is meant by "reasonable royalties," including the requirement that royalty stacking be addressed and that value associated with inclusion of a technology in the standard be excluded. 
Taken as a whole, these changes promise to resolve many of the issues that have plagued SEPs in recent years, to significantly reduce harm from SEP holdup if courts enforce them, and to greatly reduce the amount of SEP-related litigation. These changes reflect some of the recommendations made by the National Research Council in Maskus and Merrill (2013). The elements of this list have been sought in the past by antitrust agencies and economists..$^{90}$

We see substantial advantages of the new IEEE IPR policy in terms of innovation and consumer benefits. Properly implemented, these new policies allow the owners of patents that cover fundamental technologies to be richly compensated when their patents are included in an IEEE standard: the reasonable royalties per unit should reflect the $e x$ ante incremental benefits of the patented technology, which are substantial for a fundamental technology with no good substitutes, and the number of units sold can be hugely increased through standardization. Furthermore, under the IEEE IPR policy, the reasonable royalties paid for any one party's portfolio of SEPs will be reduced by considerations of royalty stacking. SEP owners and implementers will all benefit if the IEEE policy helps overcome the Cournot Complements problem that commonly arises with SEPs. ${ }^{91}$ Substantial efficiency gains may be achieved if SEP owners as well as implementers embrace these new policies, at the IEEE and at other SSOs.

So far, however, these policies have only been adopted by a single major SSO, namely the IEEE. An important policy question arising from the IEEE action is whether reform will extend to other major SSOs, notably the European Telecommunications Standards Institute (ETSI) and the International Telecommunication Union (ITU). The European Commission has made it clear for a number of years that it will take action to prevent the abuse of FRAND commitments. The European Commission has filed cases against Samsung and Motorola over abuse of SEP licensing and the violation of FRAND commitments. ${ }^{92}$ Nonetheless, we have found no official reaction by ETSI or the ITU to the IEEE reform. Nor have we detected any hint of change at ETSI or at the ITU; industry sources indicate that parties who oppose changes along the lines of those implemented by the IEEE have enough votes in both organizations to block similar reforms. This means that a substantial fraction of the flow of new SEPs will continue to feature vague FRAND commitments. Indeed, firms whose business model involves the monetization of SEPs may cease to participate in IEEE and instead 
take their technology to SSOs whose demands are less consumerfriendly. For example, just a few days after the IEEE reform, Qualcomm announced that it would not comply with the new IEEE IPR policy:

Qualcomm will continue to submit information that could be considered for inclusion in the standard, but it will set its own royalty commitment similar to the old rules, said Fabian Gonell, chief lawyer of Qualcomm's licensing business. "IEEE has approved standards even when companies have refused to make precise commitments," he said. "Since they say they're not going to force anyone, we're going to hold them to that."

A similar statement was made by InterDigital on March 24, 2015:

In a nutshell, we advised the IEEE that our company objects to their entirely new policy on patents and, going forward, on a case-by-case basis, will provide alternative licensing assurances to those specified in the 2015 policy. ${ }^{94}$

This dynamic will be very interesting to watch going forward. If the IEEE accepts commitments from patent holders that depart from its new policies and ex ante allow patent hold-up, the IEEE would open itself to the criticism that it is acting like a technology cartel rather than a welfare-enhancing organization. This could create antitrust liability for the IEEE and its members. On the other hand, if the IEEE stands by its new IPR policy and refuses to accept weaker commitments than called for under that policy, how will Qualcomm, InterDigital, and other firms seeking to monetize their SEPs respond? We will soon see whether they withdraw their technologies altogether from future Wi-Fi standards, decamp to a different SSO, or agree to abide by the new IEEE IPR policy. Stay tuned.

\section{Enforcement and Guidance from the FTC and the US DOJ}

The FTC has taken two recent enforcement actions against SEP holdup. The first case was against Bosch, a maker of automotive technology, among other businesses. The patents in question were owned by a firm being acquired by Bosch, SPX, and are relevant to two refrigeration standards. ${ }^{95}$ The FTC analysis described the problem as "SPX's suit for injunctive relief against implementers of its standard essential patents constitutes a failure to license its standard-essential patents under the FRAND terms it agreed to while participating in the standard setting 
process, and is an unfair method of competition actionable under Section 5 of the FTC Act." $" 96$

In settling the case brought by the FTC, Bosch agreed to offer a royalty-free license to all implementers desiring to manufacture the devices at issue and to no longer seek injunctions unless "the third party refuses in writing to license the patent consistent with the letter of assurance, or otherwise refuses to license the patent on terms that comply with the letter of assurance as determined by a process agreed upon by both parties (e.g., arbitration) or a court."

The second case brought by the FTC involved Motorola, then owned by Google. This case also involved a patent holder, Motorola, seeking an exclusion order based on FRAND-encumbered SEPs. As in the Bosch case, the FTC complaint describes Motorola's behavior as violating Section 5 of the FTC Act.

Google and Motorola's conduct constitute an unfair method of competition and harms competition by threatening to undermine the integrity and efficiency of the standard-setting process. ... Motorola's conduct threatens to increase prices and reduce the quality of products on the market and to deter firms from entering the market. Moreover, Motorola's conduct threatens to deny consumers the many procompetitive benefits that standard setting makes possible. ${ }^{97}$

The FTC settlement with Google required that Google resolve any disputes over the correct FRAND rate through courts or binding arbitration without recourse to injunctions, except under certain limited circumstances.

Like the FTC, the Antitrust Division of the DOJ has long been concerned about SEPs. Notably, in 2007, the DOJ and the FTC issued a major report, "Antitrust Enforcement and Intellectual Property Rights: Promoting Innovation and Competition," in which chapter 2 was entitled "Competition Concerns When Patents are Incorporated into Collaboratively Set Standards." More recently, Deputy Assistant Attorney General Renata Hesse, one of the current leaders of the Antitrust Division, has given a number of speeches describing the US DOJ's efforts to encourage SSOs to voluntarily change the way in which they handle SEPs. ${ }^{98}$ These speeches also emphasize the long-standing efforts by the DOJ to educate the United States Trade Representative (USTR), the PTO, the ITC, and other parts of the government, as well as SSOs themselves, about the competitive problems caused by SEP holdup. Top officials from the Antitrust Division have expressed their hope that volun- 
tary reform by SSOs will obviate the need for the DOJ to take antitrust enforcement action. ${ }^{99}$

However, with the notable exception of the IEEE, this voluntary approach based on persuasion has yet to induce major SSOs to make significant changes to their IPR policies. Overall, based on experience to date, it seems likely that publicizing DOJ's opinions will have little or no impact on the behavior of the most aggressive SEP holders in the absence of steps that materially change their incentives. At some point, the DOJ may need to pivot from offering guidance to taking enforcement actions. Of course, the DOJ can only bring an enforcement action if a suitable case comes to its attention. Section 1 of the Sherman Act provides the Antitrust Division with a powerful tool if the DOJ can establish that an SSO's vague or weak IPR polices constitute an agreement among competitors that limits technology competition and enriches the participants who own SEPs at the expense of consumers by allowing or enabling patent holdup. Section 2 of the Sherman Act provides the Antitrust Division with another powerful tool, given the market power inherent in an SEP associated with a successful standard. With a suitable fact pattern, a DOJ enforcement action, likely combined with private antitrust cases seeking treble damages, could provide a powerful incentive for other SSOs to make reforms along the lines of the recent IEEE IPR policy changes.

\section{Transparent Trading of Rights to Practice SEPS}

In March 2013, the Antitrust Division issued an important BRL to Intellectual Property Exchange International (IPXI). ${ }^{100}$ This letter further explains how the DOJ views licensing issues associated with SEPs.

IPXI described itself as "the world's first financial exchange that facilitates non-exclusive licensing and trading of intellectual property (IP) rights with market-based pricing and standardized terms." ${ }^{101}$ These standardized terms were embodied in "unit license rights" (ULRs), which were traded on the IPXI exchange. "Each purchaser of a ULR contract is granted the right to use the underlying technology for a pre-established number of instances (the technology unit)."102 For example, IPXI offered a ULR contract for a portfolio of 194 patents that cover technologies used in wireless chipsets that comply with the IEEE 802.11n standard, which provides higher throughput for Wi-Fi access. These SEPs were contributed by eight sponsors, including Mitsubishi, 
Sony, Philips, and the University of California. ${ }^{103}$ Each ULR granted the purchaser the right to make, use, and sell 1,000 wireless chipsets.

Because its business model involved packing together patents from multiple owners in a novel way, IPXI sought a business review letter from the DOJ. The DOJ responded by writing: "Due to inherent uncertainties and potential competitive concerns associated with IPXI's novel business model that are discussed in detail below, the Department declines to state its present enforcement intentions regarding IPXI's proposal at this time." Nevertheless, the DOJ letter is quite informative, especially regarding SEPs.

The DOJ letter recognized that the pooling of SEPs from multiple patent holders could generate efficiencies:

IPXI's platform for pooled ULRs has the potential to generate additional efficiencies by reducing the time and expense of acquiring and disseminating all the pooled patents to potential licensees, reducing the amount of stacked royalties, clearing blocking positions, and integrating technologies that are necessary to practice an industry standard or field of use. ${ }^{104}$

The DOJ also speaks approvingly of IPXI's ULRs that pool SEPs, including IPXI's requirement that patent holders provide an independent expert's opinion that the patents are indeed essential to compliance with the standard: "IPXI's definition of essentiality is consistent with other definitions of 'essentiality' that the Department has favorably reviewed to exclude substitute patents from a pool to implement a technical standard." 105

The IPXI business model offered the prospect of enhanced transparency and liquidity in the licensing of patents and what could have been a convenient and efficient mechanism to pool SEPs to help overcome problems associated with royalty stacking. The prices coming out of the IPXI exchange could have served as benchmarks for other patents for the purpose of determining FRAND royalty levels. But IPXI ceased operations in March 2015.

\section{E. The International Trade Commission as an Outlier}

During the past decade, patent owners increasingly turned to the ITC, seeking to obtain exclusion orders that prevent the importation of infringing products. The peak of this activity was reached in 2011: RPX $(2015,13)$ reports that number of initiated ITC Section 337 investiga- 
tions peaked at 67 in 2011 and has been steady at 37 or 38 during 2012, 2013, and 2014. The ITC opened 39 new investigations related to patent disputes in 2012, 43 in 2013, and 41 in 2013. ${ }^{106}$ At the end of 2014, there were 111 pending ITC investigations related to patent disputes. ${ }^{107}$

SEPs fare significantly better when they are asserted before the ITC than when they are litigated in federal court. When asserting SEPs before the ITC, patent holders prevail $49 \%$ of the time, compared with only $29 \%$ of the time in federal court. ${ }^{108}$

In addition to the higher win rate for owners of SEPs, the ITC offers two significant advantages to patent owners in comparison with brining a patent infringement action in federal court: the ITC process is significantly faster, and an exclusion order issued by the ITC is far more costly to the target firm than the most likely remedy in federal court, the awarding of damages to the patent holder equal to reasonable royalties.

As noted in the preceding, the Supreme Court's 2006 decision in eBay established conditions under which a patent holder is entitled to a permanent injunction to stop another firm found to have infringed its valid patent from continuing to infringe that patent. ${ }^{109}$ Under the $e$ Bay decision, it is very difficult for a patent holder to obtain an injunction unless monetary damages are insufficient to compensate the patent for the infringement. As Judge Posner forcefully explained, eBay implies that patent holders who have made FRAND commitments generally cannot obtain injunctions. ${ }^{110}$

To begin with Motorola's injunctive claim, I don't see how, given FRAND, I would be justified in enjoining Apple from infringing the '898 unless Apple refuses to pay a royalty that meets the FRAND requirement. By committing to license its patents on FRAND terms, Motorola committed to license the ' 898 to anyone willing to pay a FRAND royalty and thus implicitly acknowledged that a royalty is adequate compensation for a license to use that patent. How could it do otherwise?

On appeal, the CAFC agreed with Judge Posner that Motorola should not receive an injunction in this case, stating: "A patentee subject to FRAND commitments may have difficulty establishing irreparable harm." 111

The FTC, applying similar logic to that used by Judge Posner and the CAFC, urged the ITC in 2012 not to grant exclusion orders on patents subject to FRAND commitments, writing that "a royalty negotiation that occurs under threat of an exclusion order may be weighted heavily in favor of the patentee in a way that is in tension with the RAND com- 
mitment. ${ }^{112}$ In 2013, the US DOJ and the US PTO issued a joint policy statement urging the ITC to be cautious about issuing exclusion orders related to FRAND-encumbered patents. ${ }^{113}$

Despite these urgings, in June 2013, the ITC went forward and awarded an exclusion order related to a Samsung SEP that it found to be infringed by certain Apple smartphones and tablets. ${ }^{114}$ In August 2013, US Trade Representative Michael Froman disapproved (nullified) that exclusion order. Citing the joint US DOJ-US PTO policy statement, he wrote the following:

The Policy Statement expresses substantial concerns, which I strongly share, about the potential harms that can result from owners of standards-essential patents ("SEPs") who have made a voluntary commitment to offer to license on terms that are fair, reasonable, and non-discriminatory ("FRAND"), gaining undue leverage and engaging in "patent hold-up."115

The reasons US Trade Representative Froman disapproved the order are (a) there are other remedies available to these patent holders, (b) there remains the possibility of an exclusion order if the infringing party refuses to pay a royalty rate that has been determined to be FRAND, and (c) an exclusion order is possible if the infringing party is not subject to the jurisdiction of the federal courts. This balance is designed to limit patent holdup by owners of SEPs while allowing those patent holders to collect the reasonable royalties due to them. However, it is worth noting that disapproval of an ITC order is under the control of the president (with authority delegated to the trade representative) on a case-by-case basis and is not a general policy. Moreover, the Froman letter does not categorically state that exclusion orders based on SEPs will be disapproved, and the ITC does not appear to have accepted the economic logic underlying the statements by the FTC, US DOJ, US PTO, and the USTR.

Indeed, the ITC appears to take the contrary view that a patent holder must have the ability to threaten exclusion, even before a reasonable rate has been determined, in order to receive a reasonable royalty rate in negotiations with an implementer. ${ }^{116}$ This is a markedly different conclusion than that drawn by the Supreme Court, the US DOJ, the FTC, and other authorities on patents and competition. Judge Posner, in his inimitable style, swiftly eviscerates the ITC's apparent argument, writing: "You can't obtain an injunction for a simple breach of contract on the ground that you need the injunction to pressure the defendant to 
settle your damages claim on terms more advantageous to you than if there were no such pressure."117

Despite Judge Posner's compelling logic, the ITC appears to be exclusively focused on patent holdout rather than holdup. The ITC InterDigital Decision affirmatively states that there is no patent holdup in this industry:

First, InterDigital is, by the terms of the ETSI policy agreement, entitled to be adequately and fairly rewarded for its IP. There is no proof that they have been negotiating in bad faith, and in fact it is the respondents that have taken advantage of the complainant and manufactured, marketed, and profited on goods without taking a license to the IP at issue. While there may be a hypothetical risk of holdup, we have evidence that it is not a threat in this case, or in this industry. ${ }^{118}$

This factual assertion about the wireless telecommunications industry stands in stark contrast to the conclusions reached by every other regulatory body in the United States, as discussed in the preceding.

The ITC InterDigital Case goes on to describe a world where implementers are seeking to avoid paying reasonable royalties and, absent ITC action, will have a "safe haven, where they are free to avoid their own obligations under the agreements." ${ }^{\prime 19}$ Oddly, this statement entirely ignores the remedies available to SEP owners through the federal courts under the Patent Act.

The judge in the ITC InterDigital case appears to believe that implementers will be able to game the system if exclusion orders are only available once a FRAND rate has been determined and the implementer refuses to pay the FRAND royalties that are due to the patent owner. On this point, it is important to distinguish two notions of what constitutes a "reasonable royalty."

For the purposes of a FRAND determination, the reasonable royalty rate is the one that would be negotiated between the SEP owner and the implementer prior to the inclusion of the technology in the standard. These negotiations would recognize that the patent in question may in fact not be valid and may not be infringed. We call this the "FRAND royalty rate." In contrast, the notion of a "reasonable royalty" for the purpose of calculating patent damages is the rate that would be negotiated prior to the inclusion of the technology in the standard but assuming that the patent is valid and infringed. The assumptions of validity and infringement are routinely made for the purpose of calculating patent damages, because such damages only arise once a patent has in 
fact been ruled valid and infringed. We call this the "patent damages royalty rate."

As a general principle, not confined to SEPs, the patent damages royalty rate is greater than the FRAND royalty rate, perhaps far greater, because the latter incorporates uncertainty about validity and infringement. Because patent holders often lose when they bring infringement actions, the FRAND royalty rate typically involves a substantial discount based on patent quality, that is, the probability that the patent will be found valid and infringed by the implementer in question. Therefore, a target firm that refuses to pay a FRAND rate bears the risk that it will pay a much higher patent damages royalty rate if the patent is ruled valid and infringed. This is true for SEPs in the absence of ITC exclusion orders, just as it is true for all patents for which an injunction will not be granted under $e B a y$. The ITC InterDigital Case appears to miss this basic point.

At this point, the ITC remains a policy outlier regarding SEPs. Unlike the ITC, the other agencies in the US government correctly recognize that innovation and consumer welfare is promoted by policies that confine injunctions and exclusion orders on SEPs to circumstances in which the implementer has refused to pay a FRAND rate as determined by a neutral authority. It remains to be seen whether the ITC will issue exclusion orders on SEPs following the Froman disapproval letter. The White House has suggested that the ITC standard for issuing exclusion orders be changed legislatively to better align it with the traditional four-factor test from eBay that applies in the federal courts. ${ }^{120}$ This would reduce uncertainty about the circumstances under which the ITC will issue exclusion orders based on SEPs while better aligning rewards and contributions for SEP owners.

\section{F. Judicial Determination of FRAND Rates}

In 2013, Judge Robart in the Western District of Washington ruled on the range of FRAND rates for Motorola's SEPs in order to determine whether Motorola had breached its contractual commitment to offer a FRAND rate to Microsoft. ${ }^{121}$ Microsoft claimed that Motorola had violated its commitment to the JEDEC, the applicable SSO, with an unreasonably high licensing demand of $\$ 4$ billion. The court found that the correct FRAND payment was $\$ 1.8$ million, or less than $0.1 \%$ of the original

demand. These numbers illustrate well the problem with vagueness in FRAND: the huge range of licensing demands that are possible ex post. 
The Microsoft $v$. Motorola case was the first instance in the United States where a patent holder was found to have breached a FRAND commitment. Judge Robart's carefully reasoned decision created precedent that is helping to make it more difficult for owners of SEPs to engage in patent holdup. However, progress along these lines appears to be limited due to the particular legal stance of the Microsoft v. Motorola case. This case involved Microsoft suing Motorola under Washington law as a third-party beneficiary of the JEDEC FRAND contract. This "contract law approach" by an implementer such as Microsoft is only available for a subset of SSOs. For example, the ITC has ruled that FRAND commitments under ETSI are interpreted under French law and are very limited: "the [ETSI] agreement is not a contract itself, but rather an agreement in principal," which does not create a binding contract to license at a FRAND rate, but only to negotiate. ${ }^{122}$

The subsequent Innovatio case in the Northern District of Illinois also resulted in a FRAND rate dramatically below what the SEP owner had originally offered. ${ }^{123}$ The original demand from Innovatio was $6 \%$ of the value of "Wi-Fi's contribution" to the final product, which was calculated to be as high as $\$ 40$ per chip. The court found the correct RAND rate to be 9.56 cents per chip. In this case the judicial determination of FRAND was $0.2 \%$ of the $\$ 40$ license rate initially demanded for a bar code scanner.

In each of these cases, the court discusses patent holdup and the fact that the FRAND commitment is designed to prevent patent holdup. In each of these cases, the court also embraces the idea that the appropriate compensation for the technology does not include the value of standardization itself.

Importantly, the CAFC articulated these same themes in December 2014, in the Ericsson v. D-Link case. ${ }^{124}$ In this case, the jury awarded damages to Ericsson of $\$ 10$ million, based on 15 cents per infringing device. The CAFC vacated that damages award, finding that the jury had not been given sufficient instructions concerning the meaning of FRAND. In particular, the trial judge should have instructed the jury concerning which Georgia-Pacific factors were relevant and the nature of Ericsson's FRAND commitment. The CAFC stated:

Because SEP holders should only be compensated for the added benefit of their inventions, the jury must be told to differentiate the added benefit from any value the innovation gains because it has become standard essential.... [The jury] must be told to consider the difference between the added value of the technological invention and the added value of that invention's standardization. ${ }^{125}$ 
Interestingly, in January 2015, Ericsson filed suit against Apple at the ITC and in the US District Court for the Eastern District of Texas. Ericsson claims that Apple is violating 41 patents that apply to both the iPhone and iPad, including SEPS related to 2G and LTE. ${ }^{126}$ Apple's response to the Ericsson suit asserts that Ericsson's FRAND demand is for $1.5 \%$ of the end price of the device, and that Ericsson believes it is "entitled to an approximate 25 percent share of a total LTE 'royalty stack.'"127 Ericsson has stated in other venues that FRAND royalties should be driven by market forces and reflect the value of the standardized technology. ${ }^{128}$ These points were explicitly rejected by the CAFC in Ericsson v. D-Link. ${ }^{129}$ Only time will tell whether the recent rulings regarding FRAND rates at the District Court level and by the CAFC will deter SEP owners from beginning their negotiations by making royalty demand that are more than two orders of magnitude larger than what are later determined to be FRAND royalty rates.

Our conclusion regarding the determination of FRAND royalty rates, at least in the United States, is that important steps have been taken over the last few years, both at the district court level and by the Court of Appeals for the Federal Circuit, to clarify how FRAND rates will be determined in judicial proceedings.

\section{G. Summary}

However, our overall conclusions regarding SEPs are more mixed. Policy and legal changes that have reduced the ability of SEP owners to engage in patent holdup appear to have stalled out, especially as regards reform of the IPR rules at SSOs other than the IEEE. If so, this could have important effects on innovation and efficiency. For example, the "Internet of Things" is a new and growing area where royalty stacking and patent holdup appear to be very real dangers. Devices of all sorts, from thermostats to railroad cars to refrigerators, are being given connectivity using standards developed by SSOs. The price of those chips, and whether the IP contained in them costs $\$ 5$ or $\$ 0.50$ or $\$ 0.005$, will determine the nature of new applications and the rate of adoption.

Failure to prevent patent holdup relating to tomorrow's information technology and communications standards is likely to cause significant social welfare loss in the years ahead. If new and more effective private solutions relating to standard setting do not emerge to promote innovation and protect consumers, antitrust enforcement is one of the only remaining remedies that seems feasible. 


\section{Conclusions}

Over the past five years, the rewards provided to patent owners in the United States have become more closely matched with the value of the technology they contribute. When rewards and contributions are aligned, economic efficiency is promoted because investments into developing new technologies are commensurate with benefits. These changes have come from legislation, the federal courts, and policy statements and enforcement actions by regulators of various types. However, at this juncture, we see a substantial gap persisting between the ability of some patent owners to monetize their patents and the contributions provided by the technology underlying those patents. With the "Internet of Things" poised to create economic growth, this is a problem worthy of further research and policy attention.

\section{Endnotes}

We thank Joshua Lerner and Scott Stern for their comments on an earlier draft. For acknowledgments, sources of research support, and disclosure of the authors' material financial relationships, if any, please see http:/ / www.nber.org/chapters/c13587.ack.

1. The AIA did make a number of changes to the rules governing patent litigation: it placed limits on the ability of patent holders to name multiple defendants in a single patent infringement lawsuit, it modestly expanded the prior user defense, and it removed the "best mode" defense. But none of these changes directly addressed the problems identified and discussed in this article.

2. The model in Scott Morton and Shapiro (2014) provides conditions under which a PAE promotes rather than retards innovation. While the organizational form of the entity asserting the patent does not directly enter into this determination, any approach to patent assertion that involves high transaction costs will be more likely to retard innovation, ceteris paribus. Scott Morton and Shapiro (2014) report evidence that patent assertion by PAEs is a very leaky bucket, that is, only a small fraction of the costs imposed on target firms makes its way back as a reward to the entities that initially conducted the R\&D leading to the patents being asserted. Reforms that reduce the transaction costs associated with patent litigation improve the operation of the patent system so long as they do not worsen the alignment between patentee reward and contribution.

3. See PTO (2015) and http://patentlyo.com/patent/2014/10/number-patents-force .html.

4. See Love $(2013,1335$, table 5$)$. The comparable number for practicing entities is 11.6 years. The average lag from patent issuance to the end of litigation is 13.2 years for patents asserted by nonpracticing entities and 8.6 years for patents asserted by practicing entities.

5. See RPX (2014a, 35, chart 52). The median priority date of patents asserted by operating companies in 2013 was three years later, 2001. Also see RPX (2014a, 36, chart 54).

6. A specific patent claim may be of low quality because it is likely invalid or because it is not infringed. Invalidity is a general property of the patent claim, while noninfringement is specific to the target products or processes in a given patent infringement action.

7. Georgia-Pacific Corp. v. United Plywood Corp. 318 F. Supp. 1116 (S.D.N.Y, 1970).

8. Uniloc USA, Inc. v. Microsoft Corp. 632 F.3d 1292 (2011).

9. See, for example, Durie and Lemley (2010). 
10. See LaserDynamics Inc. v. Quanta, 694 F.3d 51 (2012). Unfortunately, however, the CAFC has expressly ruled as a matter of law that the cost to the target firm of adopting a noninfringing technology is not an upper bound on the reasonably royalty. See Mars. Inc. v. Coin Acceptors, Inc. 527 F.3d 1359 (2008) at 1373. Reconciling this decision with the hypothetical negotiation framework that underlies the calculation of reasonable royalties seems very difficult.

11. See Lex Machina (2015, 22, fig. 39).

12. See Lex Machina $(2015,22$, fig. 39). Figure 44 shows that $\$ 5.4$ billion of the compensatory and enhanced damages awarded between 2005 and 2014 was in the Eastern District of Texas.

13. See Lex Machina (2014b, 3, fig. 4).

14. See Lex Machina (2014a, 12, fig. 27).

15. See PwC (2014, 6, chart 2a). Given the substantial increase in the number of patent infringement cases brought over this time period, this presumably reflects in significant part a more aggressive approach taken collectively by patent holders, who are now pursuing cases they would not have brought 10 years ago, causing the marginal case to yield significantly lower damages than the average case.

16. See PwC (2014, 6, chart 2b). This difference persists and has been growing, despite the fact that practicing entities can receive damages for lost profits, while nonpracticing entities can only receive reasonable royalties.

17. See PwC (2014, 9, chart 4c). Presumably, at least in part this reflects the choice by patent holders with the most promising cases to try their case before a jury rather than a judge. Chart 4 a shows that juries were used in $62 \%$ of the patent cases since 2000 . But one cannot help but wonder if juries are more generous than judges in awarding damages in patent infringement cases, ceteris paribus.

18. See PwC (2014, 10, chart 6a). Some cases involve both lost profits and reasonable royalty damages.

19. eBay Inc. v. MercExchange, L.L.C. , 547 U.S. 388 (2006).

20. For a noncompeting patent owner, while awarding ongoing royalties under $e B a y$ is different than awarding reasonable royalties for past infringement, no new calculation is needed. As noted in the preceding, the level of reasonable royalties is determined by a hypothetical ex ante negotiation prior to the infringing party first making specific investments in the products or services later found to infringe. In contrast, for patent holders who do compete against the infringing firm and, thus, are seeking lost profit damages, permanent injunctions will fit into the eBay framework because it is often much harder to determine compensatory damages for ongoing infringement, even if one has already calculated lost profits for past infringement (itself an intricate task). In such cases, a court may find it attractive to delay the imposition of the permanent injunction in order to allow the infringing firm time to develop a noninfringing alternative.

21. One sharp critic of PAEs is none less than Richard Posner, who writes: "It is extremely difficult to discern any possible social benefit from trolls, and extremely easy to discern substantial social costs." Plus this: "It's not just that patent trolls don't do anything that encourages innovation; they impair innovation." See "Patent Trolls," available at http://www.becker-posner-blog.com/2013/07/patent-trollsposner.html.

22. See Scott Morton and Shapiro (2014, fig. 1).

23. See RPX (2014a, 39, chart 59) and RPX (2015, 12, chart 17). In 2014, individual inventors accounted for $8 \%$ of these patent infringement cases; noncompeting entities, that is, operating companies asserting patents outside their areas of products and services, for $2 \%$; and universities for $1 \%$. We again thank RPX for sharing their data with us.

24. See the citations provided in Scott Morton and Shapiro (2014). See also Feldman and Frondorf (forthcoming), who find that PAEs gain leverage by targeting technology companies that are planning to complete an Initial Public Offering (IPO) of their stock.

25. See Feldman and Lemley $(2015,28)$.

26. See Feldman and Lemley $(2015,27)$. Perhaps more surprisingly, Feldman and Lemley found that licensing from practicing entities and universities also was typically not associated with technology transfer.

27. http://www.essentialpatentblog.com/wp-content/uploads/sites/234/2014/08 /2014-08-08-omb-pae-study.pdf. 
28. http://www.ftc.gov/system/files/documents/federal_register_notices/2014/05 /140519agencyinfocollectionfrn.pdf.

29. Commissioner Julie Brill gave a speech at American Antitrust Institute in December 2014 in which she expressed hope that the FTC would issue a report on PAEs by the end of 2015. See page 4 in https://www.ftc.gov/system/files/documents/public_state ments/604381/brill_-_aai_ccia_pae_speech_12-10-14.pdf.

30. Another recent example is the FTC's study of data brokers, which resulted in a report entitled "Data Brokers: A Call for Transparency and Accountability," available at https://www.ftc.gov/system/files/documents/reports/data-brokers-call-transparency -accountability-report-federal-trade-commission-may-2014/140527databrokerreport .pdf.

31. See Federal Trade Commission's "FTC Settlement Bars Patent Assertion Entity From Using Deceptive Tactics," available at http://www.ftc.gov/news-events/press -releases /2014/11/ftc-settlement-bars-patent-assertion-entity-using-deceptive.

32. Ibid.

33. See RPX, "2014 NPE Litigation: New and Smaller Targets," available at http:// www.rpxcorp.com/2015/01/09/2014-npe-litigation-new-and-smaller-targets-2/. The number of patent infringement cases brought by operating companies also fell, from 1,845 to 1,667 .

34. See RPX $(2015,3)$.

35. Ibid.

36. See http://www.ipnav.com/blog/erich-spangenbergs-patent-predictions-for -2015 /. His prediction assumes that Congress will pass patent reform legislation in 2015 including a strong fee-shifting provision. Note that this prediction may not apply to SEPs, which we consider later in the paper.

37. Lu (2015) finds a large negative effect of the Supreme Court's Alice decision (see the following) on prices commanded by patent portfolios, but this effect is measured over a short period of time and is not statistically significant.

38. http://www.reuters.com/article/2014/12/23/us-rpx-rockstar-ip-idUSKBN0K11AI 20141223.

39. http://www.reuters.com/article/2013/11/26/us-qualcomm-china-idUSBRE9AO 0E820131126?feedType=RSS\&feedName=technologyNews.

40. See "Qualcomm Fined 6.088 Billion RMB and Required to Change Licensing Policy by Chinese Regulator," available at http://www.patentexp.com/?cat=1177.

41. Ibid.

42. See Joe Mullin (2014), “For World's Biggest Troll, First Patent Case Ends up in Tatters," Arstechnica. Available at http://arstechnica.com/tech-policy/2014/04/for-worlds -biggest-troll-first-patent-case-ends-up-in-tatters/.

43. See Dan Levine (2014), “Capital One Defeats Patent Lawsuit Brought by Intellectual Ventures." April 16, 2014. Available at http://www.reuters.com/article/2014/04/17 /capital-one-fin-ruling-idUSL2N0N900G20140417.

44. 134 S. Ct. 2347. We discuss the Alice case in the following.

45. See Dan Levine (2014), "Big Patent Owner Intellectual Ventures Cuts Staff 5 Pct." Available at http://www.reuters.com/article/2014/02/13/intellectualventures-layoffs -idUSL2N0LI1DN20140213.

46. See Ashley Vance (2014), "Mass Layoffs Hit Intellectual Ventures' Patent Factory." Available at http://www.bloomberg.com/bw/articles/2014-08-19/intellectual-ventures -layoffs-hit-a-fifth-of-its-workforce.

47. Ibid.

48. See Scott Morton and Shapiro (2014).

49. http://www.bloomberg.com/bw/articles/2014-09-04/intellectual-ventures -patent-troll-funds-startups-new-products.

50. http://www.bloomberg.com/bw/articles/2014-09-04/intellectual-ventures -patent-troll-funds-startups-new-products\#p2.

51. https://ivin.intven.com/session/new.

52. http://www.intellectualventures.com/inventor-network/.

53. However, submitting an invention to IVIN grants IV "a worldwide, royalty-free, non-exclusive, perpetual, irrevocable and sublicenseable license to use, distribute, repro- 
duce, modify, or publicly display" that information. An inventor must agree to this condition before revealing the details of his or her invention for consideration by IV.

54. http://www.marketwatch.com/story/apple-ordered-to-pay-533-million-in -patent-case-2015-02-25 and http://www.reuters.com/article/2015/02/25/us-ip-apple -verdict-idUSKBNOLT0E720150225.

Smartflash was founded by inventor Patrick Racz early in the twenty-first century as a way to market and commoditize his patents, some of which date back to 1999. As a nonpracticing entity, the firm operates solely through patent licensing and litigation. Using its clutch of seven patents, all attributed to co-inventor Racz, the firm sued game makers Game Circus and Kings Isle Entertainment in 2014. Both companies settled out of court.

See http://appleinsider.com/articles/15/02/26/fresh-off-533m-victory-smartflash -files-another-patent-suit-against-apple.

55. In the House, Democrats voted in favor of the AIA by 136-50, and Republicans voted in favor by 168-67. See http://clerk.house.gov/evs/2011/roll491.xml.

56. Democrats voted in favor by 130 to 64 , and Republicans voted in favor by 195 to 27 . See http://clerk.house.gov/evs/2013/roll629.xml.

57. Senator Hatch introduced S.1612, the Patent Litigation Integrity Act, in October 2013 and Senator Leahy introduced S.1720, the Patent Transparency and Improvements Act, in November 2013

58. As discussed in the following, in 2014 the Supreme Court addressed fee shifting in patent cases in a pair of cases.

59. Legislation very similar to H.R. 9 was introduced in late April 2015 in the Senate Judiciary Committee by Chairman Chuck Grassley together with Ranking Member Senator Patrick Leahy. This legislation, the Protecting American Talent and Entrepreneurship Act (PATENT Act) seeks to clarify pleading standards, protect end users, limit early discovery, enable more fee shifting, curb abusive demand letters, and increase transparency regarding patent ownership.

60. White House Task Force on High-Tech Patent Issues, June 4, 2013, available at http://www.whitehouse.gov/the-press-office/2013/06/04/fact-sheet-white-house-task -force-high-tech-patent-issues.

61. Executive Office of the President, "Patent Assertion and U.S. Innovation," available at www.whitehouse.gov/sites/default/files/docs/patent_report.pdf.

62. White House Task Force on High-Tech Patent Issues, June 4, 2013, available at http://www.whitehouse.gov/the-press-office/2013/06/04/fact-sheet-white-house-task -force-high-tech-patent-issues.

63. Two recommendations relate to the ITC, which we discuss in the following. Two directly involve the PTO, which is discussed immediately below. The final recommendation is to "use demand letter transparency to help curb abusive suits." This last recommendation relates to the FTC's enforcement action against MPHJ discussed in the preceding.

64. The fifth executive action is to strengthen the enforcement process for ITC exclusion orders.

65. http://www.uspto.gov/patent/initiatives/uspto-led-executive-actions-high-tech -patent-issues.

66. Ewing and Feldman (2012) document 1276 shell companies used by Intellectual Ventures. IV has acknowledged that it uses shell companies to purchase and hold patents. In comments filed with the PTO, IV has stated that it seeks to keep some of its patent holdings secret so as not to reveal its "technology roadmap." See http://www.uspto.gov /patents/law/comments/ao-e_intellectualventures_20140424.pdf.

67. See http://www.gpo.gov/fdsys/pkg/FR-2015-02-05/pdf/2015-02398.pdf.

68. The Supreme Court clearly was in no mood to defer to the specialized court established to handle patent litigation. For example, in Limelight v. Akamai 134 S. Ct. 2111 (2014), the Supreme Court wrote: "The Federal Circuit's analysis fundamentally misunderstands what it means to infringe a method patent."

69. While the 2014-2015 Supreme Court term will not compare with the dramatic 2013-2014 term, it has already yielded one major patent case in which the Supreme Court reversed the CAFC. In Teva Pharmaceuticals USA v. Sandoz, 135 S. Ct. 831 (2015), the Court 
ruled 7-2 that the CAFC could only overrule the trial court's construction of a patent claim if the lower court had committed a "clear error." Under Teva, the CAFC's role in claim construction is significantly diminished in comparison with the previous de novo review standard the CAFC had established for itself.

70. 134 S. Ct. 2354, quoting Association for Molecular Pathology v. Myriad Genetics 133 S. Ct. 2107 (2013). In Myriad, the court found that isolated human genes were not patentable subject matter. The court also cited Bilski v. Kappos, 561 U.S. 593 (2010) and Mayo Collaborative Services v. Prometheus Laboratories, 132 S. Ct. 1289 (2012). Bilski involved a method of hedging and Mayo involved a medical diagnostic method. One of the key precedents here goes all the way back to the invention of the telegraph, O'Reilly v. Morse 56 U.S. 62 (1854), where the Supreme Court found certain claims in Morse's patent to be overly broad.

71. 134 S. Ct. 2357.

72. See, for example, "Data reveals a surge in the success rate of motions to dismiss after Alice," available at http://www.iam-media.com/blog/Detail.aspx?g=458b952d -eaf8-4f84-be69-85c488556896.

73. See http://patentlyo.com/media/2014/11/GrayLeCozDuan.pdf.

74. Octane Fitness v. ICON Health \& Fitness, Inc., 134 S. Ct. 1749 (2014) and Highmark, Inc. v. Allcare Health Mgmt. Sys., Inc., 134 S. Ct. 1744 (2014).

75. See the arguments in Scott Morton and Shapiro (2014).

76. See US Department of Justice and US Patent and Trademark Office (2013).

77. See Maskus and Merrill (2013).

78. See RPX (2014b, 9, table 1.1). These numbers are calculated on a defendant-patent basis, so each patent asserted against each defendant counts as one observation. On a unique patent basis, the patent holder win rates are $19 \%$ and $67 \%$ respectively. These data include all patent infringement actions brought in US district courts from January 2005 through June 2014. The most recent outcome at verdict, initial determination, or final determination is counted.

79. For a brief overview, see the U.S. DOJ IEEE BRL, available at http://www.justice .gov/atr/public/busreview/311470.pdf.

80. The IEEE policy is here: http://standards.ieee.org/develop/policies/bylaws /approved-changes.pdf.

81. Joint guidelines DOJ-FTC Joint Guidelines on Intellectual Property licensing. See the DOJ BRL at: http://www.justice.gov/atr/public/busreview/311470.pdf.

82. http://grouper.ieee.org/groups/pp-dialog/drafts_comments/SBBylaws_100614 _redline_current.pdf.

83. http://grouper.ieee.org/groups/pp-dialog/drafts_comments/SBBylaws_100614 _redline_current.pdf.

84. See http://www.justice.gov/atr/public/busreview/311470.pdf. The IEEE request for a review by the Antitrust Division can be found at http://www.justice.gov/atr /public/busreview/request-letters/311483.pdf.

85. Hesse (2013) also articulates the current enforcement policy of the Antitrust Division regarding SSOs.

86. DOJ IEEE BRL, page 6.

87. DOJ IEEE BRL, page 9.

88. DOJ IEEE BRL, page 15

89. DOJ IEEE BRL, page 9.

90. See Kai-Uwe Kuhn, Fiona Scott Morton, and Howard Shelanski (2013), “Standard Setting Organizations Can Help Solve the Standard Essential Patents Licensing Problem" CPI Antitrust Chronicle, March 2013 (special issue) as well as the US DOJ-FTC joint IP guidelines. See also Farrell et al. (2007). https://www.competitionpolicyinternational .com/assets/Free/ScottMortonetalMar-13Special.pdf

91. Indeed, since SEPs are Cournot Complements, an IPR policy preventing patent holdup helps overcome the problem of supramonopoly pricing associated with complementary inputs used in fixed proportions.

92. http://europa.eu/rapid/press-release_IP-14-489_en.htm?locale=en and http:// europa.eu/rapid/press-release_IP-14-490_en.htm?locale=en. 
93. See Susan Decker and Ian King (2015), “Qualcomm Says it Won't Follow New Wi-Fi Rules on Patents," available at http://www.bloomberg.com/news/articles/2015-02-11 /qualcomm-says-new-wi-fi-standard-rules-unfair-may-not-take-part.

94. See Richard Lloyd (2015), "InterDigital Reveals That, Like Qualcomm, it is Reworking Relationship with IEEE After Introduction of New Patent Policy," available at http:// www.iam-media.com/Blog/Detail.aspx?g=8c9676dd-6bbd-4d6c-b3e5-9a5ddeb36581. The InterDigital letter to the IEE is available at http://www.interdigital.com/wp -content/uploads/2015/03/Letter-to-IEEE-SA-PatCom.pdf.

95. "SAE International ACRRR industry standards, J-2788 and J-2843, which govern the operation of ACRRR machines that handle the two most common types of air conditioning refrigerant in vehicles today." See https://www.ftc.gov/sites/default/files /documents/cases/2013/04/121126boschanalysis.pdf.

96. https://www.ftc.gov/sites/default/files/documents/cases/2013/04/121126bosch analysis.pdf, page 4 .

97. https://www.ftc.gov/sites/default/files/documents/cases/2013/01/130103 googlemotorolaanalysis.pdf, page 4 .

98. http://www.justice.gov/atr/public/speeches/speech-hesse.html. See also Hesse (2012a, 2012b, 2013, 2014a, 2014b).

99. See, for example, Hesse (8 November, 2013, page 4, 12):

"How can we address this problem? One way is through post hoc antitrust suits against holders of F/RAND-encumbered SEPs who try to engage in patent hold-up. The Federal Trade Commission (FTC) and the European Commission (EC) have demonstrated that this approach can be successful in some cases, and several recent decisions from U.S. courts have provided substantial guidance in this area. But, post hoc litigation also can be costly and time-consuming. A more efficient solution would rely on collaboration within the standards industry to improve patent policies at standards bodies. (p 4)"

"In sum, I believe the Division's competition advocacy, in combination with the efforts of other agencies and the courts, is bringing some much-needed guidance ... We will continue our work in this area with the hope that the policies governing the use of such standards-essential patents will become even more procompetitive. (page 12)"

100. http://www.justice.gov/atr/public/busreview/295151.pdf. Subsequent to the issuance of this BRL, Shapiro served as a consultant to IPXI.

101. https://www.ipxi.com/inside-ipxi/the-exchange.html.

102. https://www.ipxi.com/offerings/ulr-contracts.html.

103. https://www.ipxi.com/public-files/wfn1-offering-summary.pdf.

104. http://www.justice.gov/atr/public/busreview/295151.pdf, page 7.

105. http://www.justice.gov/atr/public/busreview/295151.pdf, page 10.

106. See Lex Machina (2015, 28, fig. 49$)$.

107. See Lex Machina (2015, 28, fig. 51) and Lex Machina (2014a, app. 1). The appendix lists all pending ITC patent investigations as of December 31, 2013.

108. See RPX (2014b, 9, table 1.1). These numbers are calculated on a defendant-patent basis, so each patent asserted against each defendant counts as one observation. On a unique patent basis, the patent holder win rates are 33\% at the ITC and $19 \%$ in federal court.

109. eBay Inc. v. MercExchange, L.L.C. , 547 U.S. 388 (2006).

110. Apple Inc. and NeXT Software v. Motorola Inc., 869 F. Supp. 2d 901 (2012) at 914.

111. Apple Inc. and NeXT Software v. Motorola Inc., 757 F.3d 1286 (2014) at 1332. The CAFC left open the possibility that an injunction may be warranted if the infringer refuses to pay a FRAND royalty.

112. https://www.ftc.gov/sites/default/files/documents/advocacy_documents/ftc -comment-united-states-international-trade-commission-concerning-certain-gaming-and -entertaining/1206ftcgamingconsole.pdf.

113. http://www.justice.gov/atr/public/guidelines/290994.pdf. Like the CAFC, the US DOJ and US PTO state that exclusion orders may be appropriate if the putative licensee refuses to pay what has been determined to be a FRAND royalty. They also state: 
"An exclusion order could be appropriate if the putative licensee is not subject to the jurisdiction of a court that could award damages" (page 7).

114. Commission Opinion in the Matter of Certain Electronic Devices Including Wireless Communications Devices, Portable Music and Data Processing Devices, and Tablet Computers, Investigation No. 337-TA-794, June 2013.

115. https://ustr.gov/sites/default/files/08032013\%20Letter_1.PDF, p. 2. Such disapprovals by the USTR are extremely rare. This was the first veto since 1987.

116. See especially Initial Determination on Violation of Section 337 and Recommended Determination on Remedy and Bond, In the Matter of Certain Wireless Devices with 3G and/or 4G Capabilities and Components Thereof," Investigation No. 337-TA868, June 2014, Administrative Law Judge Theodore R. Essex, public version, especially at pages 123-126, henceforth "ITC InterDigital Decision." See also Initial Determination on Remand, In the Matter of Certain 3G Mobile Handsets and Components Thereof," Investigation No. 337-TA-613, April 2015, Administrative Law Judge Theodore R. Essex," public version, especially pages $54-67$. Whether the Commission as a whole will support ALJ Essex's public interest analysis remains to be seen.

117. Apple Inc. and NeXT Software v. Motorola Inc., 869 F. Supp. 2d 901 (2012) at 915.

118. ITC InterDigital Decision at page 123.

119. ITC InterDigital Decision at page 125.

120. Legislative Recommendation No. 5, White House Task Force on High-Tech Patent Issues, available at http://www.whitehouse.gov/the-press-office/2013/06/04/fact -sheet-white-house-task-force-high-tech-patent-issues.

121. See Microsoft Corp. v. Motorola, Inc., 864 F. Supp. 2d 1023, 1030-33 (W.D. Wash. 2012) and Microsoft Corp. v. Motorola, Inc., 854 F. Supp. 2d 993, 999-1001 (W.D. Wash. 2012).

122. ITC InterDigital Decision.

123. In re Innovatio IP Ventures, LLC Patent Litig., 2013 WL 5593609 (N.D. Ill. Oct. 3, 2013).

124. Ericsson Inc. v. D-Link Systems Inc. et. al., 773 F.3d 1201 (2014).

125. Ericsson v. D-Link at 1233.

126. See "Ericsson Sues Apple Over Patent Licensing, Seeks to Block iPhone and iPad Sales, available at http://techcrunch.com/2015/02/27/ericsson-sues-apple-over-patent -licensing-seeks-to-block-iphone-and-ipad-sales/.

127. Apple v Telefoniktiebolaget lm Ericsson CV 15 0154, Complaint for Declaratory Judgment, January 2015, page 12.

128. See https:/ / www.youtube.com/watch?v=8a07jTJIZbc\&spfreload=10 (minute 1:30): "FRAND royalties should be driven by market forces. True FRAND royalties reflect the value of the standardized technology to the consumer."

129. "When dealing with SEPs, there are two special apportionment issues that arise. First, the patented feature must be apportioned from all of the unpatented features reflected in the standard. Second, the patentee's royalty must be premised on the value of the patented feature, not any value added by the standard's adoption of the patented technology. These steps are necessary to ensure that the royalty award is based on the incremental value that the patented invention adds to the product, not any value added by the standardization of that technology" (Ericsson v. D-Link at 1232.)

\section{References}

Contreras, Jorge, and Richard J. Gilbert. Forthcoming. "A Unified Framework for RAND and Other Reasonable Royalties." Berkeley Technology Law Journal

Contreras, Jorge, and David L. Newman. 2014. "Developing a Framework for Arbitrating Standards-Essential Patent (SEP) Disputes." Journal of Dispute Resolution 2014 (1): 23-51.

Durie, Daralyn J., and Mark A. Lemley. 2010. "A Structured Approach to Calculating Reasonable Royalties." Lewis E Clark Law Review 14:627-52. 
Ewing, Tom, and Robin Feldman. 2012. "The Giants among Us." Stanford Technology Law Review 1:1-61. https://journals.law.stanford.edu/sites/default / files/stanford-technology-law-review-stlr/online/feldman-giants-among -us.pdf.

Farrell, Joseph, John Hayes, Theresa Sullivan, and Carl Shapiro. 2007. "Standard Setting, Patents and Hold-Up." Antitrust Law Journal 74:603-70. http:// faculty.haas.berkeley.edu/shapiro/standards2007.pdf.

Farrell, Joseph, and Carl Shapiro. 2008. "How Strong Are Weak Patents?" American Economic Review 98 (4): 1347-69.

Feldman, Robin, and Evan Frondorf. Forthcoming. "Patent Demands and Initial Public Offerings." Stanford Technology Law Review. http://papers.ssrn .com/sol3/papers.cfm?abstract_id=2591648.

Feldman, Robin, and Mark Lemley. 2015. “Do Patent Licensing Demands Mean Innovation?" Iowa Law Review 101. http://papers.ssrn.com/sol3/papers .cfm?abstract id=2565292.

Hesse, Renata. 2012a. "The Antitrust Division and SSOs: Continuing the Dialogue." November. http://www.justice.gov/atr/public/speeches/288580.pdf.

_. 2012b. "Six 'Small' Proposals for SSOs Before Lunch." October. http:// www.justice.gov/atr/public/speeches/287855.pdf.

— 2013. "The Art of Persuasion Competition Advocacy at the Intersection of Antitrust and Intellectual Property." November. http://www.justice.gov /atr/public/speeches/301596.pdf.

—. 2014a. "At the Intersection of Antitrust \& High-Tech: Opportunities for Constructive Engagement." January. http:/ / www.justice.gov /atr/public /speeches/303152.pdf.

. 2014b. "A Year in the Life of the Joint DOJ-PTO Policy Statement on Remedies for F/RAND Encumbered Standards-Essential Patents." May. http:/ / www.justice.gov/atr/public/speeches/304638.pdf.

Lemley, Mark, and Carl Shapiro. 2007. "Patent Hold-Up and Royalty Stacking." Texas Law Review 85 (7): 1991-2049.

. 2013. "A Simple Approach to Setting Reasonable Royalties for StandardEssential Patents." Berkeley Technology Law Journal 28:1135-66.

Lex Machina. 2014a. "2013 Patent Litigation: Year in Review." https://lex machina.com/2014/10/2013-patent-litigation-year-review/.

_. 2014b. "Patent Litigation Damages Report." http://pages.lexmachina .com/Damages-Report.html.

—. 2015. "2014 Patent Litigation: Year in Review." https://lexmachina .com/resources/.

Love, Brian. 2013. "An Empirical Study of Patent Litigation Timing: Could a Patent Term Reduction Decimate Trolls Without Harming Innovators?" University of Pennsylvania Law Review 161:1309-59.

Lu, Jack. 2015. "Patent Market Dynamics and the Impact of Alice and the AIA." IPWatchdog, May 17. http://www.ipwatchdog.com/2015/05/17/patent -market-dynamics-aia-and-alice/id=57728/.

Maskus, Keith, and Steve Merrill, eds. 2013. Patent Challenges for StandardSetting in the Global Economy: Lessons from Information and Communications Technology. Committee on Intellectual Property Management in StandardSetting Processes, Board on Science, Technology and Economy Policy, National Research Council of the National Academies. http://download.nap .edu/cart/download.cgi?\&record_id=18510.

Menell, Peter. 2014. "Reinvigorating Patent Notice through Faithful Implemen- 
tation of Section 112(b) Claim Indefiniteness Provision." http://papers.ssrn .com/sol3/papers.cfm?abstract_id=2403902

PwC. 2013. "2013 Patent Litigation Study: Big Cases Make Headlines, While Patent Cases Proliferate."http://www.pwc.com/en_US/us/forensic-services /publications/assets/2013-patent-litigation-study.pdf.

. 2014. "2014 Patent Litigation Study: Big Cases Make Headlines, While Patent Cases Proliferate." http://www.pwc.com/en_US/us/forensic-ser vices/publications/assets/2014-patent-litigation-study.pdf.

RPX. 2014a. "2013 NPE Litigation Report." http://www.rpxcorp.com/wpcon tent/uploads/2014/01/RPX-2013-NPE-Litigation-Report.pdf.

—.2014b. "StandardEssentialPatents:HowDoTheyFare." https://www.rpx corp.com/wp-content/uploads/2014/01/Standard-Essential-Patents-How -Do-They-Fare.pdf.

. 2015. "2014 NPE Litigation Report."

Scott Morton, Fiona, and Carl Shapiro. 2014. "Strategic Patent Acquisitions." Antitrust Law Journal 79 (2): 463-99.

Shapiro, Carl. 2007. "Patent Reform: Aligning Reward and Contribution." In Innovation Policy and the Economy, vol. 8, ed. Adam Jaffe, Josh Lerner, and Scott Stern, 111-56. Chicago: University of Chicago Press.

. 2010. "Injunctions, Hold-Up, and Patent Royalties." American Law and Economics Review 12 (2): 280-318.

US Department of Justice and Federal Trade Commission. 2007. "Antitrust Enforcement and Intellectual Property Rights: Promoting Innovation and Competition." http://www.justice.gov/atr/public/hearings/ip/222655.pdf.

US Department of Justice and US Patent and Trademark Office. 2013. "Policy Statement on Remedies for Standards-Essential Patents Subject to Voluntary F/RAND Commitments." http://www.justice.gov/atr/public/guidelines /290994.pdf.

US Patent and Trademark Office. 2014. "Preliminary Examination Instructions in View of the Supreme Court Decision in Alice Corporation Pty. Ltd. V. CLS Bank International, et al." http://www.uspto.gov/sites/default/files/patents /announce/alice_pec_25jun2014.pdf.

_. 2015. "Performance \& Accountability Report, Fiscal Year 2014." http:// www.uspto.gov/about/stratplan/ar/USPTOFY2014PAR.pdf. 